Front. Bus. Res. China 2010, 4(1): 101-129

DOI 10.1007/s11782-010-0005-3

RESEARCH ARTICLE

Fuxiu Jiang, Yaohui Qu, Zhengfei Lu, Yan Li

\title{
Product Market Competition and Dynamic Adjustment in Capital Structure
}

\author{
(C) Higher Education Press and Springer-Verlag 2010
}

\begin{abstract}
Based on the balanced panel data of Chinese listed firms from 1999 to 2004, this paper studies the relationship between product market competition and dynamic adjustment in capital structure. Results show that, from both static and dynamic perspectives, product market competition and its changes have significant influence on the degree of deviation of a firm's present capital structure from its targeted one. Specifically, the more intensive the product market competition, the smaller the capital structure deviation. Meanwhile, capital structure deviation tends to decrease in a market characterized by increasingly fierce competition. However, evidence also reveals that product market competition and the speed of the capital structure adjustment are independent from one another.
\end{abstract}

Keywords product market competition, capital structure, dynamic adjustment, target capital structure, adjustment speed

Translated from Jingji Yanjiu 经济研究 (Economic Research Journal), 2008, (4): 99-110

Fuxiu Jiang $(\bowtie)$

School of Business, Renmin University of China, Beijing 100872, China

E-mail: jfx@ruc.edu.cn

Yaohui Qu

School of Business, Guangdong University of Foreign Studies, Guangzhou 510420, China

E-mail: qyhgood@163.com

Zhengfei Lu

Guanghua School of Management, Peking University, Beijing 100871, China

E-mail: zflu@gsm.pku.edu.cn

Yan Li

School of Business, Renmin University of China, Beijing 100872, China

Email: liyanl1@263.net 


\section{Introduction}

Ever since Brander and Lewis' (1986) seminal research more than two decades ago, the relationship between capital structure and product market competition has become a hot issue in the field of capital structure theories. Relevant literature in recent years has reveled that firms always choose their capital structures by comprehensively taking into consideration product market competition, corporate strategy, and capital market environment. Quite a lot of research has demonstrated that a firm's capital structure is related to its product market competition (e.g., Brander and Lewis, 1986, 1988; Showalter, 1995; Jong, Nguyen and Dijk, 2007; Liu et al., 2003). The breadth and depth of capital structure theories have been further expanded thanks to these recent findings.

Per the MM Theory proposed by Modigliani and Miller (1958), under a series of rigorous assumptions, a firm's capital structure has nothing to do with its market value. However, in reality, due to the existence of company tax, bankruptcy and agency cost and other costs, a firm's capital structure does has an impact on its value. In other words, an "optimal" capital structure does exist (Kraus and Litzenberger, 1973; Scott, 1976). In addition, there has been accumulating evidence showing that a firm can realize such a structure by adjusting its asset/liability ratio, which in turn enhances the firm's value and growth rate and in the end improves its conditions (Lööf, 2004).

For a variety of reasons, however, a firm might deviate from its "optimal" capital structure. Therefore, to maximize its value, a firm needs to constantly adjust its capital structure to make it approach the optimal level. It is for this reason that dynamic capital structure adjustment has become a study focus in recent years. Researchers have reached a consensus that firms shall dynamically adjust their capital structures in accordance with changes in both internal and external environments to ensure their financial security and maximize their enterprise value.

Although there has been quite a lot of literature studying capital structure from the perspective of product market competition, and the issue of dynamic capital structure decision has recently drawn more attention from relevant researchers, little study has combined the two perspectives together. This paper aims to fill in this important gap. To begin with, we need to find empirical evidence concerning the status quo of product market competition and how do changes in product market competition influence a firm' s capital structure.

China's firms are facing a rare chance for development as well as more market uncertainty in the context of economic transition. Along with China's constant deepening of its reform and opening to the outside world in recent years and the establishment of market economy, the entry barriers to most industries have been 
removed and instantly fierce market competition has generated profound and far-reaching effects on Chinese firms' capital structure decisions.

Using data of Chinese listed companies from 1999 to 2004, this paper explores the relationship between product market competition and its changes and dynamic adjustment in capital structure. It is found that, from both static and dynamic perspectives, there is a significantly negative relationship between the intensity and changes of product market competition and adjustment of capital structure. In other words, the more intensive the market competition, the smaller the gap between a firm's present capital structure and its target capital structure. Meanwhile, firms adjust their capital structure in accordance with changes in product market competition, making their present capital structure approaching constantly targeted one.

The main contributions of this article are as follows. First, we explore the impact of product market competition on capital structure from both static and dynamic perspectives, which expand relevant study in the field of strategic financial management pioneered by Brand and Lewis. Second, this article explores the relationship between product market competition and the speed of company capital structure adjustment, which we believe further extend previous study of capital dynamic adjustment pioneered by Jalivand and Harris in 1984. Finally, it is helpful to deepen people's understanding of capital structure decision in real business world.

The rest of the article is organized as follows: In Section 2, we review and comment briefly on the relevant literature. Based on the review, we develop our hypotheses in Section 3. Section 4 establishes a model for dynamic capital structure adjustment and presents the descriptive description of main variables. Hypotheses are tested in Section 5. Conclusions and discussion are provided lastly.

\section{Literature Review}

Research on the relationship between capital structure and product market competition started with Brander and Lewis (1986). They pointed out that a firm's behavior is affected by its capital structure, and that the firm's market performances influence its financial decisions. To test these assumptions, Brander and Lewis constructed a two-phase duopoly model to analyze the impact of capital structure on a firm's market behavior under the context of uncertain market demands. Due to the effect of limited liability of debts, firms in the red tend to demonstrate more aggressive behaviors in a competitive market. The two authors' model shows that firms' capital structure affect the equilibrium of 
product market. Therefore, those far-seeing firms are motivated to optimize their financial decisions and prefect their capital structure to obtain better firm performance. In 1988, Brander and Lewis introduced the concept of "bankruptcy costs" to study the effect of a firm's debt ratio on its product market behaviors. However, even after the introduction of the variable "bankrupt cost", their research conclusions drawn in 1986 remain unaffected.

Brander and Lewis, however, only studied Cournot competition in the context of uncertain market demand. ${ }^{1}$ As we all know, there are other competition types such as Betrand competition. In addition, firms are constrained not only by uncertain market demand, but also by cost and other uncertainties. In 1995, following Brander and Lewis's line, Showalter included Betrand competition and cost uncertainty in his similar study. He found that if a firm engages in Betrand competition, under the context of uncertain cost, it would not choose to operate in the red. However, under the context of uncertain market demand, it would choose to borrow some debts to raise its product price to reduce competition in product market to a certain degree. Jong, Nguyen and Dijk (2007) also distinguished the two types of different market competition. They tested the strategic effect of debt by using data collected from American manufacturing industry. Contrary to Showalter's (1995) conclusion, they found that under both market competition types, there is a positive relationship between demand uncertainty and debt ratio, while cost uncertainty's positive relationship with debt ratio under Cournot competition turned to negative under Betrand competition.

Much of the later research has been conducted on the basis of Brander and Lewis' pioneering study in 1986. For instance, Wanzenried (2000) argued that a firm's financial decision is seriously dependent on the characteristics of its product market. Lyandres (2002) explored the relationship between "optimal" financial leverage ratio, debt maturity and aggressive business strategy. Schnitzer and Wambach (1998) studied the relationship between a firm's decisions on internal and external financing and the firm's pricing activities. However, due to the limitation of data, study in the field is seriously lacking (Lyandres, 2002), let along empirical study (Jong, Nguyen and Dijk, 2007). In addition, no theoretical or empirical consensus has been reached among the limited number of researchers in the field.

Jalivand and Harris (1984) were the earliest researchers studying corporate decisions concerning capital structure from the dynamic perspective. They argued that firms will constantly adjust their financial behaviors to fulfill their

\footnotetext{
${ }^{1}$ Cournot competition and Bertrand competition are two most frequently used competition types in oligarchic monopoly. Consequently, two corresponding competition models, namely Cournot Quantity Model and Bertrand Quantity Model, are the oldest and most important models used in economics to describe firm behaviors.
} 
long-term financial goals. Based on changes in capital structure of sampled companies in the previous eight years, Fischer, Heinkel and Zechner (1989) attempted to identify the determinants of the range of capital structure fluctuation. Rajbhandary (1997) used Indian firms as samples and constructed a preliminary model of dynamic adjustment of capital structure. However, due to difficulty in constructing a dynamic model (Wang and Zhao, 2004), little has been achieved in the field of dynamic model construction after Jalivand and Harris' pioneering work.

In recent years, along with progress in handling of dynamic panel data in econometrics, literature on the dynamic adjustment in capital structure has been accumulating. Banerjee, Heshmati and Wihlborg (2000) firstly used dynamic adjustment model and panel model to study capital structure. They found that, in most cases, firms' present capital structures always deviate from their target capital structure and the adjustment towards target structure is very slow. In their study, Banerjee, Heshmati and Wihlborg emphasized, for the first time, the long-ignored problem of adjustment cost.

Capital structure is affected by firm characteristics. Titman and Tsyplakov (2007) found that a firm's financial distress cost and whether it can maximize its shareholder and enterprise value affect the firm's speed of capital structure adjustment and the deviation degree of its present capital structure to target structure. Therefore, the speed of capital structure adjustment tends to be faster in firms meeting financial difficulties or firms characterized by less serious interest conflict between shareholders and creditors. In addition, scholars also explored the effects of return on stocks (Dittmar and Thakor, 2007), historical book debt ratio (Liu, 2005) and financial deficit on dynamic adjustment of capital structure.

Capital structure is also affected by industrial characteristics. Antoniou et al., (2002) found that the speed of capital structure adjustment vary in manufacturing industry or service industry, showing that a firm's external environment is one of the main determinants for its capital structure adjustment (Tucker and Stoja, 2007). Consistent with this conclusion, Lööf (2004) found that a country's financial structure, capital market development, and its tax system all have important impact on firms' capital structure adjustment. By comparison, the capital structure of American firms characterized by high equity dependence has the smallest deviation from optimal capital structure. In addition, compared with highly-debt-dependent Swedish firms, American firms have a greater speed of capital structure adjustment. He also found that for British firms with institutional background similar to that of American firms, although having a greater degree of capital structure deviation compared with Swedish firms, their adjustment cost is much smaller. Levy and Hennssy (2007) asserted that economic cycle also has certain impact on the dynamic adjustment in capital 
structure.

Due to the limitation of data, domestic research on the relationship between capital structure and product market competition is lacking. To the best of our knowledge, Zhu et al's case study of Yanjing Beer in 2002 is the earliest domestic study in the field. They found that when a firm anticipates increasingly intensified market competition in the future, it tends to choose a low level of debt ratio, leading to conservative financial decisions. Using data of China's listed companies, Zhao and Sun (2004) found no evidence of the correlation between financial conservation and firms' competitive strategies. They therefore assumed that China's listed companies seldom take into consideration the interaction and coordination between capital structure and product market competition when making decisions concerning capital structure governance. Liu et al (2003) found that, based on the data of China's listed companies from 1997 to 2001, there is a positive relationship between the capital structure of China's listed companies and the degree of intensity of product market competition. We can hence infer that no consensus regarding the relationship between capital structure and product market competition has been reached among domestic scholars.

As for indigenous research on the dynamic adjustment of capital structure in China, Wang and Zhao (2004) found that the dynamic model of capital structure has greater explanation power than previous static model. In addition, scholars can use dynamic model to estimate time needed for capital structure adjustment. Other domestic researchers have also conducted a series of studies on dynamic adjustment of capital structure (e.g., Tong, 2004; Xiao, 2004; Lian, 2005; Qu, 2006). However, most of these studies were conducted from the perspective of speed of capital structure adjustment and its influencing factors.

The above brief review of relevant research both at home and abroad shows that although a number of researchers have studied the relationship between capital structure and product market competition from the perspective of corporate strategies and have explored the dynamic adjustment of capital structure and its influencing factors, little research has been conducted by means of combing product market competition and dynamic adjustment of capital structure together. To fill in this gap, this article attempts to explore the relationship between capital structure and product market competition from both static and dynamic perspectives.

\section{Hypothesis Development}

A firm's decisions on capital structure are inseparable from changes in its internal and external environment. To better adapt to environmental changes, a firm will 
constantly adjusts its capital structure to keep it close to target capital structure, ${ }^{2}$ so that to ensure its financial safety and value maximization. Rajan and Zingales (1995) and Booth et al. (2001) found, after comparison of different firm capital structures in different countries, that capital structure and its adjustment are closely related to the institutional environment, macro economic factors, and firm characteristics in a country.

As a transitional economy, China's firms face rare chances for development as well as more market uncertainty. On the one hand, thanks to the rapid development of China's capital market, Chinese firms can achieve external equity financing in a more convenient way. On the other hand, due to lack of mature regulatory bodies and relevant laws, there exist serious "threshold effect" of equity financing. In addition, with the intensification of competition among banks, good-performed firms become favorite clients of increasingly profit-sensitive banks, while those poor-performed firms meet difficulties in obtaining new loans from banks. In addition, out of consideration of risk control, some banks might even call in immature loans. Under such circumstances, even if a firm notices that its present capital structure derivates from the target level, whether it can smoothly or successfully adjust its capital structure to a target one is constrained by external capital markets, such as security market or financial market. As a result, the cost of capital structure adjustment of Chinese firms is much higher than that of firms in developed countries like America and Britain (e.g., Wang and Zhao, 2004; Tong, 2004).

With the progress of China's reform and opening up and establishment of market economy, the entry barrier to most of the industries in China has been eliminated. With the intensification of competition in product market, most firms have to loosen credit for their suppliers or buyers, which affect the turnover ratio of account receivable, stocks and profit of these firms. And poorer cash flow and lower profitability in turn affect these firms' equity financing activities. Meanwhile, with performance getting worse, it becomes more difficult for these firms to conduct debt financing from banks. Under such circumstances, if a firm has high debt ratio, when meeting cash flow problems, it will be very vulnerable to financial crisis. To solve this problem, the firm might choose to adjust its capital structure downwards to make the structure approach "optimal level".

\footnotetext{
${ }^{2}$ The existence of "target capital structure" is a controversy-plagued issue. Although some theories and empirical studies claim that there is no such thing as "target capital structure", a majority of researchers agree that there exist optimal or target capital structure for most firms. Graham and Harvey's (2001) survey on 392 CEOs showed that $37 \%$ CEOs confirmed the existence of flexible target capital structure. 34\% rigorous target capital structure, $10 \%$ rigorous capital structure. As for Chinese firms, Lu et al. (2003) found, after a survey of China's listed companies, that $88 \%$ sampled companies agreed that there should be a "reasonable" target capital structure.
} 
Titman and Tsyplakow (2007) found that financial crisis tends to motivate firms optimize their capital structure. To illustrate, although a reduction in debt ratio might be beneficial to the creditor, a debt-ridden firm might choose to reduce its debt to avoid greater loss brought froth by financial crisis.

Meanwhile, a basic assumption in industrial organization theory and anti-monopoly policy is that those cash-abundant firms are capable of exploiting their cash-insufficient rivals (Tirole, 2007). For example, though have anticipated profit around the corner, a debt-ridden firm might be squeezed out of an industry earlier by its cash-abundant rivals. Such an assumption is consistent with Telser's famous "deep pocket" theory. ${ }^{3}$ Bolton and Scharfstein's (1990) study also supports the "deep pocket" theory. They pointed out that firms should lower their debt level to avoid the potential harms the exploitative behavior of their cash-abundant rivals might cause in product market. To illustrate, there were fierce "price war" in China in some industries characterized by cut-throat competitions, such as "price war of color TV" and "price war of air ticket", etc, during which many firms with poor financial performance and serious debts problems were squeezed out of their industries.

As for firms with comparatively low debt ratio while their present capital structure level considerable lower than target level, fierce competition in product market might lower the profitability of the whole industry although faced low financial risks. To improve their profit, firms will either invest more to strengthen their competitiveness or conduct strategy transition to create new profit growth points. Due to the strict restrictions over refinancing activities exerted by the China's Securities Regulatory Commission, firms are likely to use debt financing tools to raise its debt level when they have debt financing and new investment opportunities. ${ }^{4}$ Therefore, by raising new fund and entering new fields, firms are able to lower their business risks. Therefore, the fiercer the competition in a firm's industry, the smaller the absolute value of capital structure deviation of the firm.

An equation borrowed from management accounting might explain the above rationale in an easier way: A firm's total risk = business risk $\times$ financial risk. Therefore, when facing high business risk, a firm has to lower its financial risks to reduce its total risks, and vice verse.

Therefore, we develop the following hypothesis:

\footnotetext{
${ }^{3}$ According to the theory, those cash-abundant firms are likely to drive their smaller rivals out a market through "predatory" or below-cost pricing for firms with more cash can afford loss for a longer time and in the end survive the competition.

${ }^{4}$ Some firms' income might not meet the requirements of equity refinancing. However, as there are only 1400 listed companies in China and competition among domestic banks has become increasingly fierce in recent years, banks will still grant loans to firms as long as the debt ratio and financial risks are not too great.
} 
H1 The fiercer the product market competition, the smaller the absolute value of capital structure deviation.

Admit fierce market competition, there are many firms drop out of competition due to business failure or strategy transition. Meanwhile, as an industry evolves, those dominant firms might take effective measures to monopolize the industry. As market shares concentrate around leading firms in an industry, the market competition in the industry are likely to ease. However, as new comers keep on entering the industry, the competition in the industry would become intensive once again. Especially for China's market, as a transition economy, there are firms entering into or withdrawing from different industries in huge numbers. Therefore, the level of competition in many industries fluctuates constantly. In addition, Chinese government's macro adjustment policy on economy also exerts certain impact on product market competition.

$\mathrm{H} 1$ analyzes the relationship between product market competition and capital structure adjustment from a static perspective. Considering from a dynamic perspective, when competition in a product market becomes more fierce, firms will adjust their capital structure accordingly, resulting in a small deviation of their present capital structures from target ones. Therefore, we develop H2 as follows:

H2 Firms adjust their capital structure in accordance with changes in product market competition. The fiercer the competition in the product market, the smaller the absolute value of capital structure deviation.

During its development, a firm's actual capital structure always deviates from its target capital structure. In addition, a firm's target capital structure also changes along with the firm's development. However, firms always demonstrate a tendency of constantly adjusting their present capital structures to make them more consistent with target ones (Antoniou et al, 2002; Flannery and Rangan, 2006). Per strategic economics and industrial organization theories, firms always adjust their competition strategy in accordance with their rivals' financial situation (as the deep pocket theory points out). When a firm faces intensive product market competition and the firm is aware of its deviation from target capital structure, it might rapidly adjust its financial decision to reduce the deviation between present capital structure and target one to reduce possible business or financial risks. Extant literature shows that the higher a firm's business risk, the more sensitive it is to the cost of financial distress, the stronger its desire to reduce the deviation between present capital structure to target one (e.g., Flannery and Rangan, 2006; Titman and Tsyplakov, 2007), and the faster the speed of capital structure adjustment. We therefore assume that:

H3 The fiercer the competition in a product market, the faster the speed of 
capital structure adjustment of firms in the market.

\section{Methods and Variable Description}

\subsection{Dynamic Adjustment Model of Capital Structure}

Theoretically, a firm's present capital structure should be equal or close to its target capital structure. ${ }^{5}$ But in reality, due to the existence of all kinds of constraints and influences, a firm's present capital structure always deviate from its target one. After taking into consideration the unobservable company effect and time effect, we construct the following regression model to analyze the deviation of the two capital structures:

$$
\text { bias }_{i t}=\alpha+\beta X_{i t}+\mu_{i}+\lambda_{t}+v_{i t}
$$

Where bias $_{i t}$ refers to the absolute value of the deviation of the two capital structures, equalizing $\left|c s_{i t}-c s_{i t-1}^{*}\right| ; c s_{i t}$ refers to the capital structure of firm $i$ at term $t$, equalizing the firm's total debts/total assets; $c s_{i t-1}^{*}$ refers to the target capital structure of term $t$ of firm $i$ at the end of term $t-1$. However, contrary to many researchers, (e.g., Heshmati, 2002; Shinichi et al., 2004; Xiao, 2004; Tong, 2004; Lian, 2005), we use $c s_{i t-1}^{*}$ rather than $c s_{i t}^{*}$ to stand for target capital structure for it can describe a firm's actual behavior more precisely. As for other variables, $\alpha$ is a constant; $\beta$ is the coefficient of independent variable; $X_{i t}$ is all influencing factors of bias $_{i t} ; \mu_{i}$ stands for unobservable company effects; $\lambda_{i}$ stands for for unobservable company effects; $v_{i t}$ is random error; And $\mu_{i} \sim$ $\operatorname{IID}\left(0, \sigma_{\mu}^{2}\right), \lambda_{t} \sim \operatorname{IID}\left(0, \sigma_{\lambda}^{2}\right), v_{i t} \sim \operatorname{IID}\left(0, \sigma_{v}^{2}\right)$.

As a firm can not adjust its capital structure to the optimal level once and for all, partial adjustment or even reversed adjustment are always needed. Drawing on Nerlove's partial adjustment model,${ }^{6}$ we describe a firm's capital structure adjustment as follows:

$$
\begin{aligned}
& c s_{i t}-c s_{i t-1}=\delta_{i t}\left(c s_{i t-1}^{*}-c s_{i t-1}\right) \\
& \delta_{i t}=\frac{c s_{i t}-c s_{i t-1}}{c s_{i t-1}^{*}-c s_{i t-1}}
\end{aligned}
$$

\footnotetext{
${ }^{5}$ The term "target capital structure" (rather than "optimal capital structure") is used in this paper to imply that firms should constantly adjust their goals of capital structure in accordance with internal and external environment and make their present capital structure approach new target capital structure.

${ }^{6}$ Refer to Gujarati D N (2000). Lin Shaogong (Tran.) Econometrics (Third Edition). Renmin University Press. p594.
} 
Where, $\delta_{i t}$ stands for the speed of capital structure adjustment of firm i at term t; $\delta_{i t}=1$ means a firm manages to adjust its capital structure to target level within a certain period; $0<\left|\delta_{i t}\right|<1$ means the firm only partially adjust its capital structure; $\left|\delta_{i t}\right|>1$ means the firm overadjust its capital structure in a certain period; $\left|\delta_{i t}\right|>0$ means actual adjustment direction is consistent with the direction of intended adjustment, otherwise $\delta_{i t}<0 ; \delta_{i t}=0$ means there is no capital structure adjustment at all.

In reality, the speed of capital structure adjustment is affected by a number of influencing factors. By taking into consideration unobservable company effect and time effect, we construct a regression model of $\delta_{i t}$ as below:

$$
\delta_{i t}=\alpha+\beta X_{i t}+\mu_{i}+\lambda_{t}+v_{i t}
$$

Where $\alpha$ is a constant; $\beta$ is the coefficient of independent variable; $X_{i t}$ is all the influencing factors of $\delta_{i t} ; \mu_{i}$ stands for unobservable company effects; $\lambda_{i}$ stands for unobservable company effects; $v_{i t}$ is random error; And $\mu_{i} \sim$ $\operatorname{IID}\left(0, \sigma_{\mu}^{2}\right), \lambda_{t} \sim \operatorname{IID}\left(0, \sigma_{\lambda}^{2}\right), v_{i t} \sim \operatorname{IID}\left(0, \sigma_{v}^{2}\right)$.

\subsection{Choice of Proxy Variable of Target Capital Structure $c s_{i t-1}^{*}$}

As a firm's target capital structure is unobservable, a number of proxy variables are used, including a firm's mean of time-series data, industrial median, estimated value of multi-linear regression model, estimated value of Tobit model, etc. D'Mello and Farhat (2002) argued that industrial median is, though not without errors, the best one among the above proxies because firms having capital structure closer to industrial median tends to have higher company value, and vice versa. Considering the applicability of their conclusion to China's practical situation, we choose eight different proxy variables to measure target capital structure, namely the mean of time series $\left(c s^{1}\right)$, mean of annual industry $\left(c s^{2}\right)$, means of mixed industry $\left(c s^{3}\right)$, industrial mean $\left(c s^{4}\right)$, regression estimate of group means $\left(c s^{5}\right)$, regression estimate of fixed effects $\left(c s^{6}\right)$, regression estimate of random effects $\left(c s^{7}\right)$, and estimate value of Tobit regression $\left(c s^{8}\right)$. Independent variables for the regression model include firm size, profitability, growth potential, mortgage capability, non-debt tax avoidance, product uniqueness, assets liquidity, firm reputation, and business risks. Control factors include industrial and regional factors.

\subsection{Product Market Competition}

Though widely cited, the definition of market is still an open question in industrial organization theories. The most commonly used indicator of product 
market competition is the concentration ratio of a market (usually referred to as $\mathrm{CRn}$ ), cross price elasticity, etc. CRn reflects the ratio of the total output of several biggest firms to the whole industry, rather than reflects the degree of competition in the industry. In addition, as most of the data of market concentration are collected from listed companies, they can not reflect truthfully competition in the whole market. Likewise, due to the limitation of firm pricing data, it is difficult to calculate the cross price elasticity. Therefore, we argue that at a time when most of firms engage in competition in a number of product markets, ${ }^{7}$ it is more reasonable to use performance indexes to reflect the degree of competition in some product markets. For example, we assume that the better a firm's performance in a product market, the less fierce the competition in the product market, and vice verse.

Nickell (1996) pointed out that the main business service profit margin of a firm can be, to a certain degree, regarded as its "monopoly rent". A high rent implies higher entry barrier for new comers. Consequently, the degree of competition in the industry is lower. Meanwhile, when competition in a product market is fierce, firms in the market will loosen business credit in an attempt to sell more products, leading to lower inventory turnover ratio and receivables turnover ratio. Therefore, inventory turnover ratio and receivables turnover ratio can also reflect the degree of competition in a market. To avoid the limitation of one single index, we use main business service profit margin, inventory turnover ratio and receivables turnover ratio as proxy variables for product market competition in this article (reciprocals are used). We than use the main component method to combine the first two factors with eigenvalue bigger than 1 as a new index $c c_{i t}$, the bigger the index, the fiercer the competition in the product market. Meanwhile, $\Delta c c_{i t}$ is used to indicate changes in product market competition.

\subsection{Sample Selection and Data Collection}

We chose companies got listed before 1999 at Shenzhen and Shanghai stock markets as samples. As a rule, financial companies and ST, PT companies were eliminated. A total of 742 firms from 35 different industries were obtained as final samples. As shown in Table 1 and Table 2, there are 60 firms issued both A and B shares. And most of the sampled firms were from coastal areas in the east and south of China and few from the Northwest. Out of consideration of attainability of study data, we set the timeframe as 1999-2004 and got a parallel

\footnotetext{
${ }^{7}$ Jiang, Liu and $\mathrm{Lu}$ (2006) found that about 2/3 of China's listed companies engage in more than two different industries concurrently. In 2004, the mean of cross-industry operation of 899 sampled firms was 2.168 .
} 
panel data with 4452 observation values. One thing worth noticing is that we did not follow Lian's (2005) advice and delete those firms with debt ratio over 100\% or firms with abnormal profitability indexes. The reason is that a firm with debt ratio over $100 \%$ do not necessarily mean it is going to bankrupt for firms are likely to get into heavy debt out of some strategic reasons. Likewise, firms with abnormal profitability indexes might only imply that these firms are facing business risks. Simple deletion of these firms will only increase the probability of sample selection errors.

Data used in this article are from the GTA's CSMAR databank (2005). Other data were collected from http://www.cnifo.com.cn and http://www.sse.com.cn and the Databank of China's Listed Companies (1990-1999) issued by Renmin University Press in August, 1999.

Table 1 Industrial Distribution of Sampled Firms

\begin{tabular}{|c|c|c|c|c|c|}
\hline Code & Industry & $\begin{array}{c}\text { Firm } \\
\text { number }\end{array}$ & $\begin{array}{l}\text { Percentage } \\
\quad(\%)\end{array}$ & A-share & $\begin{array}{l}\mathrm{A} / \mathrm{B} \\
\text { share }\end{array}$ \\
\hline 1 & Agriculture, hunting, forestry and fishing & 17 & 2.29 & 17 & 0 \\
\hline 2 & Mining and quarrying & 9 & 1.21 & 9 & 0 \\
\hline 3 & Food & 18 & 2.43 & 18 & 0 \\
\hline 4 & Beverage & 18 & 2.43 & 15 & 3 \\
\hline 5 & Textile industry & 19 & 2.56 & 17 & 2 \\
\hline 6 & $\begin{array}{l}\text { Clothes and other textile fibers } \\
\text { manufacturing industry }\end{array}$ & 13 & 1.75 & 12 & 1 \\
\hline 7 & Petroleum Processing and Coking & 14 & 1.89 & 14 & 0 \\
\hline 8 & $\begin{array}{l}\text { Chemical raw material and chemical } \\
\text { products manufacturing industry }\end{array}$ & 53 & 7.14 & 51 & 2 \\
\hline 9 & Chemical fiber manufacturing industry & 16 & 2.16 & 15 & 1 \\
\hline 10 & $\begin{array}{l}\text { Electronic components manufacturing } \\
\text { industry }\end{array}$ & 16 & 2.16 & 13 & 3 \\
\hline 11 & Household electronic applicants & 9 & 1.21 & 8 & 1 \\
\hline 12 & $\begin{array}{l}\text { Non-metal products manufacturing } \\
\text { industry }\end{array}$ & 33 & 4.45 & 30 & 3 \\
\hline 13 & $\begin{array}{l}\text { Ferrous metal smelting and rolling } \\
\text { processing industry }\end{array}$ & 22 & 2.96 & 21 & 1 \\
\hline 14 & $\begin{array}{l}\text { Nonferrous metal smelting and rolling } \\
\text { processing industry }\end{array}$ & 13 & 1.75 & 13 & 0 \\
\hline 15 & Metal products manufacturing industry & 10 & 1.35 & 8 & 2 \\
\hline 16 & Machinery manufacturing & 19 & 2.56 & 15 & 4 \\
\hline 17 & Specified equipment manufacturing & 29 & 3.91 & 26 & 3 \\
\hline 18 & $\begin{array}{l}\text { Transportation equipment manufacturing } \\
\text { industry }\end{array}$ & 33 & 4.45 & 30 & 3 \\
\hline 19 & $\begin{array}{l}\text { Electronic machinery manufacturing } \\
\text { industry }\end{array}$ & 29 & 3.91 & 24 & 5 \\
\hline 20 & Pharmaceutical industry & 32 & 4.31 & 31 & 1 \\
\hline
\end{tabular}




\begin{tabular}{|c|c|c|c|c|c|}
\hline & & & & (Con & tinued) \\
\hline Code & Industry & $\begin{array}{l}\text { Firm } \\
\text { number }\end{array}$ & $\begin{array}{l}\text { Percentage } \\
\quad(\%)\end{array}$ & A-share & $\begin{array}{c}\mathrm{A} / \mathrm{B} \\
\text { share }\end{array}$ \\
\hline 21 & $\begin{array}{l}\text { Instruments, meters, cultural and office } \\
\text { machinery }\end{array}$ & 7 & 0.94 & 6 & 1 \\
\hline 22 & $\begin{array}{l}\text { Electric power, steam and hot water } \\
\text { production and supply }\end{array}$ & 29 & 3.91 & 26 & 3 \\
\hline 23 & Papermaking and paper products & 11 & 1.48 & 11 & 0 \\
\hline 24 & Civil engineering and construction & 11 & 1.48 & 11 & 0 \\
\hline 25 & Transport equipment and ware-housing & 29 & 3.91 & 24 & 5 \\
\hline 26 & $\begin{array}{l}\text { Telecommunication and } \\
\text { communication-related equipment } \\
\text { manufacturing }\end{array}$ & 16 & 2.16 & 15 & 1 \\
\hline 27 & Computer and relevant service & 11 & 1.48 & 10 & 1 \\
\hline 28 & $\begin{array}{l}\text { Computer and relevant equipment } \\
\text { manufacturing }\end{array}$ & 9 & 1.21 & 9 & 0 \\
\hline 29 & Other manufacturing industry & 27 & 3.64 & 23 & 4 \\
\hline 30 & Retail & 52 & 7.01 & 50 & 2 \\
\hline 31 & Business agency & 16 & 2.16 & 15 & 1 \\
\hline 32 & Real estate development and & 25 & 3.37 & 20 & 5 \\
\hline 33 & Public facility and service & 8 & 1.08 & 7 & 1 \\
\hline 34 & Tourism & 10 & 1.35 & 9 & 1 \\
\hline 35 & Others & 59 & 7.95 & 59 & 0 \\
\hline & Total & 742 & 100 & 682 & 60 \\
\hline
\end{tabular}

Table 2 Regional Distribution of Sampled Firms

\begin{tabular}{cclc}
\hline Code & \multicolumn{1}{c}{ Region } & \multicolumn{1}{c}{ Province included } & Number of firms \\
\hline a & Northeast region & Liaoning, Jilin, Heilongjiang \\
b & $\begin{array}{c}\text { Northeast coastal } \\
\text { region }\end{array}$ & Beijing, Tianjin, Hebei, Shandong & 108 \\
c & $\begin{array}{c}\text { Middle reach of } \\
\text { Huanghe River }\end{array}$ & Henan, Shanxi, Shaanxi, Inner Mongolia & 54 \\
d & $\begin{array}{c}\text { East China coastal } \\
\text { region }\end{array}$ & Shanghai, Jiangsu, Zhejiang & 173 \\
e & $\begin{array}{c}\text { Southeast China } \\
\text { coastal region }\end{array}$ & Fujian, Guangdong, Guangxi, Hainan & 138 \\
f & $\begin{array}{c}\text { Middle reach of } \\
\text { Yangtze River }\end{array}$ & Hunan, Hubei, Jiangxi, Anhui & 90 \\
g & $\begin{array}{c}\text { Southwest China } \\
\text { region }\end{array}$ & Chongqing, Sichuan, Guizhou, Yunnan, Tibet & 78 \\
h & $\begin{array}{c}\text { Northwest China } \\
\text { region }\end{array}$ & Gansu, Qinghai, Ningxia, Xinjiang & 33 \\
\hline
\end{tabular}

Note: 1 . The division of different regions is made in accordance with the method noted in the third chapter of China's Modernization Report (2004) (http://www.gsei.com.cn/ aboutgansu/ziliao/gqbgk/200401/505635.htm).

2. Firms from Hong Kong, Macro and Taiwan are excluded. 


\subsection{Descriptive Statistics of Variables}

4.5.1 Descriptive Statistics of Variables of Capital Structure Adjustment and Product Market Competition

Considering the influence of extreme values, we use medians of all variables to replace their means. The descriptive statistics of variables of capital structure adjustment and product market competition are listed in Table 3.

Table 3 Descriptive Statistics of Variables of Capital Structure Adjustment and Product Market Competition

\begin{tabular}{|c|c|c|c|c|c|c|c|}
\hline Indexes & Observant points & Mean & Median & S.D. & Skewness & Kurtosis & Range \\
\hline$c s_{i t}^{\text {Tdebt }}$ & 4452 & 0.4547 & 0.4544 & 0.1848 & 1.418 & 20.488 & 3.616 \\
\hline$c s_{i t}^{\text {Sdebt }}$ & 4452 & 0.3897 & 0.3778 & 0.1812 & 1.800 & 22.916 & 3.564 \\
\hline$c S_{i t}^{\text {Ldebt }}$ & 4452 & 0.0648 & 0.0296 & 0.0886 & 2.138 & 0.073 & 0.6411 \\
\hline$\Delta c s_{i t}^{\text {Tdebt }}$ & 3710 & 0.0198 & 0.0131 & 0.1102 & 3.397 & 117.740 & 3.958 \\
\hline$\Delta c s^{\text {Sdebt }}$ & 3710 & 0.0179 & 0.0117 & 0.1133 & 2.740 & 102.463 & 3.9767 \\
\hline$\Delta c s^{L d e b t}$ & 3710 & 0.0041 & 0.0000 & 0.0701 & -0.312 & 7.673 & 0.9572 \\
\hline bias $_{i t}^{4}$ & 4367 & 0.1331 & 0.1139 & 0.1044 & 1.842 & 10.780 & 1.3206 \\
\hline$c c_{i t}$ & 4414 & 0.0000 & 0.0819 & 0.7073 & 28.038 & 1170.879 & 40.085 \\
\hline$\Delta c c_{i t}$ & 3661 & 0.0166 & 0.0109 & - & -33.127 & 1358.521 & 40.569 \\
\hline
\end{tabular}

Note: Due to space limitation, we only provide the descriptive statistics of bias $_{i t}$ here.

As shown in Table 3, the average total debt ratio of sampled firms is 0.454 , average short-term and long-term debt ratio are 0.3778 and 0.0296 , respectively, showing that most of the debts are short termed. Judging from standard errors, skewness, and Kurtosis, the fluctuation of short-term debt is consistent with that of total debt, but not with long-term debt. The average degree of deviation of sampled firms' present capital structures from target one is $11.39 \%$, showing that the deviation prevails among most of the firms. Statistics also show that the competition in product market intensifies by $1.09 \%$ every year (average degree of competition is $8.19 \%$ ). The results of range show that the degree of competition and its dynamic fluctuation vary greatly among different industries and firms, while the differences of capital structure and its dynamic adjustment is comparatively smaller among different industries and firms.

4.5.2 Correlation Analysis of the Degree of Deviation of Capital Structure and its Adjustment Speed by Using Different Methods

As above, we use eight different methods to calculate the degree of deviation of 
the capital structure of China's listed companies from their target capital structure. Table 4 presents the correlation between the results of all these eight methods.

Table 4 Degrees of Capital Structure Deviation Calculated by Using Eight Different Methods and the Pearson Coefficients of Capital Structure Adjustment

\begin{tabular}{|c|c|c|c|c|c|c|c|c|c|}
\hline & $\delta_{i t}^{1}$ & $\delta_{i t}^{2}$ & $\delta_{i t}^{3}$ & $\delta_{i t}^{4}$ & $\delta_{i t}^{5}$ & $\delta_{i t}^{6}$ & $\overline{\delta_{i t}^{7}}$ & $\delta_{i t}^{8}$ & \\
\hline bias $_{i t}^{1}$ & & 0.000 & 0.001 & 0.010 & -0.002 & 0.000 & -0.003 & -0.006 & $\delta_{i t}^{1}$ \\
\hline bias $_{i t}^{2}$ & $0.389^{\mathrm{a}}$ & & 0.007 & 0.020 & 0.000 & 0.000 & 0.001 & 0.001 & $\delta_{i t}^{2}$ \\
\hline bias $_{i t}^{3}$ & $0.446^{\mathrm{a}}$ & $0.951^{\mathrm{a}}$ & & 0.004 & 0.002 & 0.005 & $0.032^{\mathrm{b}}$ & $0.035^{\mathrm{b}}$ & $\delta_{i t}^{3}$ \\
\hline $\operatorname{bias}_{i t}^{4}$ & $0.448^{\mathrm{a}}$ & $0.946^{\mathrm{a}}$ & $0.988^{\mathrm{a}}$ & & -0.002 & -0.006 & 0.007 & 0.004 & $\delta_{i t}^{4}$ \\
\hline bias $_{i t}^{5}$ & $0.364^{\mathrm{a}}$ & $0.646^{\mathrm{a}}$ & $0.646^{\mathrm{a}}$ & $0.648^{\mathrm{a}}$ & & -0.010 & -0.003 & -0.004 & $\delta_{i t}^{5}$ \\
\hline bias $_{i t}^{6}$ & $0.388^{\mathrm{a}}$ & $0.632^{\mathrm{a}}$ & $0.647^{\mathrm{a}}$ & $0.639^{a}$ & $0.662^{\mathrm{a}}$ & & 0.004 & 0.002 & $\delta_{i t}^{6}$ \\
\hline bias $_{i t}^{7}$ & $0.425^{\mathrm{a}}$ & $0.771^{\mathrm{a}}$ & $0.775^{\mathrm{a}}$ & $0.772^{\mathrm{a}}$ & $0.847^{\mathrm{a}}$ & $0.809^{\mathrm{a}}$ & & -0.002 & $\delta_{i t}^{7}$ \\
\hline \multirow[t]{2}{*}{ bias $_{i t}^{8}$} & $0.343^{\mathrm{a}}$ & $0.694^{\mathrm{a}}$ & $0.714^{\mathrm{a}}$ & $0.704^{\mathrm{a}}$ & $0.704^{\mathrm{a}}$ & $0.706^{\mathrm{a}}$ & $0.831^{\mathrm{a}}$ & & \\
\hline & bias $_{i t}^{1}$ & bias $_{i t}^{2}$ & bias $_{i t}^{3}$ & bias $_{i t}^{4}$ & bias $_{i t}^{5}$ & bias $_{i t}^{6}$ & bias $_{i t}^{7}$ & $\operatorname{bias}_{i t}^{8}$ & \\
\hline
\end{tabular}

Note: $1 . \delta_{i t}^{1}, \delta_{i t}^{2}, \delta_{i t}^{3}, \delta_{i t}^{4}, \delta_{i t}^{5}, \delta_{i t}^{6}, \delta_{i t}^{7}$ and $\delta_{i t}^{8}$ represent respectively eight capital structure adjustment speeds calculated by adopting eight different methods, namely $c s^{1}, c s^{2}, c s^{3}, c s^{4}, c s^{5}, c s^{6}, c s^{7}$ and $c s^{8}$.

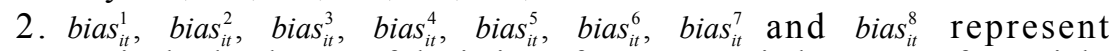
respectively the degree of deviation of present capital structure from eight different target capital structures, namely $c s^{1}, c s^{2}, c s^{3}, c s^{4}, c s^{5}, c s^{6}, c s^{7}$ and $c s^{8}$. Numbers in the table are the Pearson coefficients.

3. "a" and "b" stand for significance at 0.01 and 0.05 levels, respectively (two tailed).

As shown in Table 4, the correlation among the eight degree of deviation calculated by using eight different target capital structure levels is high (significant at 0.01 level, two tailed). However, no significant correlation is found among the eight adjustment speeds calculated by using eight different target capital structure levels. Although $\delta_{i t}^{3}$ is significantly related to $\delta_{i t}^{7}$ and $\delta_{i t}^{8}$ at 0.05 level, the correlation coefficient is small, which means that a firm's capital structure adjustment speed might vary greatly with different target capital structures.

\subsubsection{Analysis of Capital Structure Adjustment}

We divide capital structure adjustment into several types, namely appropriate adjustment, partial adjustment and overadjustment. Empirical analysis of the above several adjustment patterns are shown in Table 5.

As shown, there are only $1.3 \%-2.0 \%$ observation values can adjust 
precisely their capital structure to a targeted level; $13 \%-27 \%$ overadjust their capital structure towards target one; and about $1 / 3$ partially adjust. As for the direction of capital structure adjustment, about half of the adjustment was convergent by nature, in other words, to make present capital structure close to target level. This fact shows that there does exist so-called "target capital structure" for many firms. About one third of the adjustment is divergent by nature, including 19\%-28\% partial adjustment cases and 11\%-16\% over adjustment cases. This divergent adjustment might be a result of equity financing or unstable business operation. There is only $4 \%-11 \%$ firms do not adjust their capital structure.

Table 5 Capital Structure Adjustment in Sampled Firms (unit: 1\%)

\begin{tabular}{|c|c|c|c|c|c|c|c|c|c|c|}
\hline \multicolumn{3}{|c|}{ Adjustment description } & \multirow{2}{*}{$\frac{\delta_{i t}^{1}}{26.6}$} & \multirow{2}{*}{$\begin{array}{c}\delta_{i t}^{2} \\
15.1\end{array}$} & \multirow{2}{*}{$\frac{\delta_{i t}^{3}}{14.6}$} & \multirow{2}{*}{$\frac{\delta_{i t}^{4}}{14.9}$} & \multirow{2}{*}{$\frac{\delta_{i t}^{5}}{18.0}$} & \multirow{2}{*}{$\frac{\delta_{i t}^{6}}{13.7}$} & \multirow{2}{*}{$\begin{array}{c}\frac{\delta_{i t}^{7}}{17.1} \\
17\end{array}$} & \multirow{2}{*}{$\begin{array}{c}\frac{\delta_{i t}^{8}}{17.1} \\
17\end{array}$} \\
\hline & Over adjustment & $\delta_{i t}^{j}>0.05$ & & & & & & & & \\
\hline $\begin{array}{l}\text { Convergent } \\
\text { adjustment }\end{array}$ & $\begin{array}{l}\text { Approp } \\
\text { adjus }\end{array}$ & $1.05 \geqslant \delta_{i t}^{j}$ & 2.0 & 1.5 & 1.3 & 2.0 & 1.5 & 1.4 & 1.9 & 1.8 \\
\hline & Partial & & 29.3 & 32.0 & 32.4 & 31.6 & 35.4 & 36.1 & 34.3 & 34.4 \\
\hline Total & & & 57.9 & 48.6 & 48.3 & 48.5 & 54.9 & 51.2 & 53.3 & 52.3 \\
\hline Diverg & & $\delta_{i t}^{j}>-1$ & 19.9 & 27.7 & 27.8 & 27.1 & 23.4 & 26.0 & 24.5 & 24.6 \\
\hline & Over adjustment & $\delta_{i t}^{j} \leqslant$ & 15.6 & 11.8 & 11.6 & 12.1 & 11.8 & 11.0 & 12.0 & 11.9 \\
\hline Total & & $\delta_{i t}^{j} \leqslant-0.05$ & 35.5 & 39.5 & 39.4 & 39.2 & 35.2 & 37.0 & 36.5 & 35.5 \\
\hline $\begin{array}{l}\text { No } \\
\quad \text { adjustment }\end{array}$ & $\begin{array}{l}\text { No change in } \\
\text { capital structure }\end{array}$ & $-0.05 \leqslant \delta_{i t}^{j} \leqslant 0.05$ & 4.7 & 10.0 & 10.4 & 10.1 & 8.0 & 9.9 & 8.2 & 8.3 \\
\hline
\end{tabular}

Note: 1 . Considering that a firm's debt might change slight due to reasons like cross-fiscal year account payable, etc, we allowed a 5\% error when calculating the items of "appropriate adjustment" and "no change in capital structure".

2. Total amount is not $100 \%$ due to data missing.

\section{Empirical Testing}

This article explores, from both static and dynamic perspectives, the impact of product market competition and its changes on the capital structure deviation (from target structure) and its adjustment speed.

5.1 The Impact of Product Market Competition on the Dynamic Adjustment of Capital Structure

Drawing on empirical research both at home and abroad (e.g., Banerjee, Heshmati and Wihlborg, 2000; Lööf, 2004; Qu, 2006), we summarize factors influencing capital structure deviation and its adjustment speed as follows:

Firm size. Generally, bigger firms can afford higher transaction cost induced by capital structure adjustment. In addition, bigger firms are more transparent in 
information disclosure. All these make it easier for bigger firms to issue new bonds or borrow new debts. Accordingly, we assume that there is a positive relationship between firm size and capital structure deviation and adjustment speed. However, compared with small firms, big firm are likely to follow the Pecking Order Theory, namely they might prefer internal financing to external debt financing. Under such circumstance, there might be a negative relationship between firm size and capital structure deviation and adjustment speed. Considering both cases, the relationship between firm size and capital structure deviation and adjustment speed is uncertain. In this paper, we use the natural logarithm of a firm's total assets at the end of its previous fiscal year to represent the firm size (size for short).

Growth capability. On the one hand, fast-growing firms need huge amount of external funds, thus making the capital structure deviating from target one. One the other hand, according to the agency theory, creditors tend to exert all kinds of constrains over fast-growing firms, thus increasing agency cost of debt (meaning decelerated debt financing and reduced degree of capital structure deviation). In this paper, we choose the growth ratio of total assets to represent a firm's growth capability (growth for short).

Profitability. According to the trade-off theory, firms with stronger profitability tend to seek higher level of debt to minimize tax payment. In addition, according to the proposition of free cash flow, external shareholder might compel management team to borrow more debts to reduce abuse of free cash flow, leading to accelerated debt financing speed and greater degree of capital structure deviation. However, due to information asymmetry, banks can not sort good-performed firms from bad-performed ones. As a result, banks will raise the interest rate of their loans, forcing firms turn to internal funds, which will in turn reduce external debt financing and lower the degree of capital structure deviation. In this paper, we choose a firm's net return on assets to indicate its profitability (profitability for short).

Mortgage capability. According to the trade-off theory, when a firm goes into liquidation, it is easy to handle those tangible assets to reduce the cost of financial distress. However, the Pecking Order Theory argues that as tangible assets can be used as a mortgage, which will reduce the degree of information asymmetry from the creditors' perspective. Based on the above two theories, we believe that a higher percentage of tangible assets in a firm's total assets is beneficial to its financing activities, leading to a greater degree of capital structure deviation. In this article, we use (net value of fixed assets + inventory)/total assets to indicate a firm's mortgage capability (mortgage for short).

Business risk. The impact of business risk on capital structure adjustment is uncertain. On the one hand, according to the trade-off theory, higher fluctuation 
in a firm's profit will increase its risk of paying loan interests, which in turn leads to higher degree of expected cost of financial distress. Consequently, firms with bigger business risk tend to reduce debt financing. Therefore, higher level of business risk will lower the speed of capital structure adjustment and reduce the deviation between a firm's present capital structure and its target capital structure. On the other hand, according to the China Securities Regulatory Commission's requirements on rationed shares and new shares issuing, higher level of business risk will lower a firm's chance of equity financing and thus increase it possibility of debt financing. And an increased debt financing will in turn speed up a firm's capital structure adjustment. In this article, we use the standard deviation of a firm's gross profit rate to indicate its business risk (risk for short).

Non-debt tax shields. According to the trade-off theory, the strongest motive behind loan seeking is to use the loan interest to avoid tax payment. Other non-debt tax avoidance methods, such as depreciation, however, will discourage such a motive. As depreciation can, sometimes, bring extra cash flow to a company, we can expect that non-debt tax shields can lower the speed of capital structure adjustment and reduce the degree of capital structure deviation. In this article, we use accumulated depreciation/total assets to indicate non-debt tax shields (ndts for short).

Product uniqueness. Firms producing unique or highly-specialized products tend to have equally specialized employees and suppliers. In addition, these firms are irreplaceable in the eye of their clients. Therefore, when such firms go bankruptcy, their clients, suppliers and employees are going to suffer big losses, too. As a result, to reduce the danger of bankruptcy and potential loss of other stakeholders, firms producing unique products tend to lower their debt ratio, leading to rather stable capital structure in these firms. In this article, we use (operating expenses + overhead expenses)/income from main business to indicate product uniqueness (unique for short).

Asset liquidity. With a higher degree of liquidity, a firm can pay short-term debt easier, which is beneficial for obtaining more short-term debts (which of course will also lead to a bigger deviation between present capital structure to target one). In reality, firms can obtain cash flow buy sell out some stocked goods and reduce the deviation of capital structure. In this article, we use liquidity ratio to indicate asset liquidity of a firm (liquidity for short).

Firm reputation. Firms with a rather long history might be more likely to build a good reputation. Other things being equal, "old" firms might have stronger debt financing capabilities. However, "old" firms with bad loan record might meet greater difficulty in obtaining external funds, thus reducing capital structure deviation. In this article, we use firm age to indicate firm reputation (age for short).

Cash dividend. Cash dividend distribution reduces a firm's cash flow. In order 
to guarantee the cash needed for future development, after the distribution, a firm might increase its debt ratio, leading to a greater degree of capital structure deviation. To reflect the impact of cash dividend distribution on capital structure deviation, we add in a dummy variable of cash dividend distribution ( $\left.D^{\text {dividend }}\right)$, which equals 1 if cash dividend is distributed, and 0 otherwise.

Cash requirement. Greater cash requirement usually implies greater business risks. Out of consideration of business safety, a firm might try to reduce its capital structure deviation. In this article, we use $f d_{i t}$ to stand for cash requirement (cash requirement $=$ cash dividend distribution + capital expenditure + net increase of working capital-net operating cash flow after tax).

Firm ownership. In China, non-state-owned enterprises are eager to expand compared with state-owned enterprises. Meanwhile, they tend to meet greater difficulty in financing, such as prejudice from state-owned banks. As a result, we assume that non-state-owned firms have greater degree of capital structure deviation and smaller speed of capital structure adjustment. In this paper, we use $D^{\text {ownership }}$ to represent the nature of firm ownership. If a firm is state-owned, $D^{\text {ownership }}$ equals 0 , and 1 otherwise.

As there are 60 sampled firms issued both A and B share (688 observation values altogether). To compare these firms with those A-share firms, we add in another dummy variable $D^{\text {share }}$. If a firm issues only A shares, $D^{\text {share }}$ equals 0 , and 1 otherwise. Likewise, we also add another two control dummy variables to stand for industry ( $\left.D^{\text {industry }}\right)$ and district $\left(D^{\text {district }}\right)$, respectively.

After adding the above control variables, we then conduct an empirical test on the impact of product market competition on capital structure deviation and the speed of capital structure adjustment.

\subsection{Impact of Product Market Competition on Capital Structure Deviation}

The estimated values of the impact of product market competition on the absolute degree of capital structure deviation based on different models are presented in Table 6 .

Table 6 Impact of Product Market Competition on Eight Different Levels of Capital Structure Deviation

\begin{tabular}{|c|c|c|c|c|c|c|c|c|}
\hline \multirow{2}{*}{$\begin{array}{c}\text { Independent } \\
\text { variables }\end{array}$} & \multicolumn{8}{|c|}{ Degree of capital structure deviation } \\
\hline & bias $_{i t}^{1}$ & bias $_{i t}^{2}$ & bias $_{i t}^{3}$ & bias $_{i t}^{4}$ & $\operatorname{bias}_{i t}^{5}$ & bias $_{i t}^{6}$ & bias $_{i t}^{7}$ & bias $_{i t}^{8}$ \\
\hline$c c_{i t}$ & $\begin{array}{l}-0.0065^{\mathrm{a}} \\
(-4.85)\end{array}$ & $\begin{array}{l}-0.0037^{b} \\
(-2.04)\end{array}$ & $\begin{array}{l}-0.0037^{\mathrm{b}} \\
(-1.97)\end{array}$ & $\begin{array}{l}-0.0035^{\mathrm{c}} \\
(-1.85)\end{array}$ & $\begin{array}{l}-0.0006 \\
(-0.30)\end{array}$ & $\begin{array}{l}-0.0033^{c} \\
(-1.76)\end{array}$ & $\begin{array}{l}-0.0015 \\
(-0.83)\end{array}$ & $\begin{array}{l}-0.0014 \\
(-0.74)\end{array}$ \\
\hline size $_{i t}$ & $\begin{array}{l}-0.0056^{\mathrm{a}} \\
(-3.10)\end{array}$ & $\begin{array}{l}-0.0018 \\
(-0.67)\end{array}$ & $\begin{array}{l}-0.0031 \\
(-1.11)\end{array}$ & $\begin{array}{l}-0.0034 \\
(-1.20)\end{array}$ & $\begin{array}{l}0.0049^{b} \\
(2.01)\end{array}$ & $\begin{array}{l}-0.0001 \\
(-0.04)\end{array}$ & $\begin{array}{l}0.0011 \\
(0.42)\end{array}$ & $\begin{array}{l}-0.0099^{\mathrm{a}} \\
(-3.47)\end{array}$ \\
\hline
\end{tabular}


(Continued)

\begin{tabular}{|c|c|c|c|c|c|c|c|c|}
\hline \multirow{2}{*}{$\begin{array}{c}\text { Independent } \\
\text { variables }\end{array}$} & \multicolumn{8}{|c|}{ Degree of capital structure deviation } \\
\hline & bias $_{i t}^{1}$ & bias $_{i t}^{2}$ & bias $_{i t}^{3}$ & bias $_{i t}^{4}$ & bias $_{i t}^{5}$ & bias $_{i t}^{6}$ & bias $_{i t}^{7}$ & bias $_{i t}^{8}$ \\
\hline mortgage $_{i t}$ & $\begin{array}{l}-0.0058^{\mathrm{c}} \\
(-1.91)\end{array}$ & $\begin{array}{l}-0.0061^{\mathrm{d}} \\
(-1.42)\end{array}$ & $\begin{array}{l}-0.0053 \\
(-1.22)\end{array}$ & $\begin{array}{l}-0.0064^{\mathrm{d}} \\
(-1.43)\end{array}$ & $\begin{array}{l}0.0301^{\mathrm{a}} \\
(7.03)\end{array}$ & $\begin{array}{l}-0.0020 \\
(-0.45)\end{array}$ & $\begin{array}{l}0.0002 \\
(0.05)\end{array}$ & $\begin{array}{l}-0.0083^{\mathrm{c}} \\
(1.90)\end{array}$ \\
\hline profit $_{i t}$ & $\begin{array}{l}0.0007^{\mathrm{c}} \\
(1.94)\end{array}$ & $\begin{array}{l}0.0013^{\mathrm{a}} \\
(2.70)\end{array}$ & $\begin{array}{l}0.0008^{\mathrm{c}} \\
(1.71)\end{array}$ & $\begin{array}{l}0.0008^{\mathrm{c}} \\
(1.67)\end{array}$ & $\begin{array}{l}0.0008^{\mathrm{c}} \\
(1.68)\end{array}$ & $\begin{array}{l}0.0018^{\mathrm{a}} \\
(3.74)\end{array}$ & $\begin{array}{l}0.0018^{\mathrm{a}} \\
(3.94)\end{array}$ & $\begin{array}{l}0.0013^{\mathrm{a}} \\
(2.69)\end{array}$ \\
\hline$n d t s_{i t}$ & $\begin{array}{l}-0.0234^{c} \\
(-1.85)\end{array}$ & $\begin{array}{l}0.0085 \\
(0.46)\end{array}$ & $\begin{array}{l}0.0082 \\
(0.43)\end{array}$ & $\begin{array}{l}0.0087 \\
(0.45)\end{array}$ & $\begin{array}{l}-0.0559^{\mathrm{a}} \\
(-3.22)\end{array}$ & $\begin{array}{l}0.0081 \\
(0.40)\end{array}$ & $\begin{array}{l}-0.0245^{\mathrm{d}} \\
(-1.37)\end{array}$ & $\begin{array}{l}d-0.0204 \\
(-1.05)\end{array}$ \\
\hline grow $_{i t}$ & $\begin{array}{l}0.0004 \\
(0.36)\end{array}$ & $\begin{array}{l}-0.0007 \\
(-0.45)\end{array}$ & $\begin{array}{l}-0.0024^{\mathrm{d}} \\
(-1.39)\end{array}$ & $\begin{array}{l}d-0.0018 \\
(-1.01)\end{array}$ & $\begin{array}{l}0.0218^{\mathrm{a}} \\
(12.35)\end{array}$ & $\begin{array}{l}0.0054^{\mathrm{a}} \\
(3.11)\end{array}$ & $\begin{array}{l}0.0050^{\mathrm{a}} \\
(2.99)\end{array}$ & $\begin{array}{l}0.0074^{\mathrm{a}} \\
(4.38)\end{array}$ \\
\hline unique $_{i t}$ & $\begin{array}{l}0.0006 \\
(0.36)\end{array}$ & $\begin{array}{l}0.0022 \\
(0.92)\end{array}$ & $\begin{array}{l}-0.0015 \\
(-0.64)\end{array}$ & $\begin{array}{l}-0.0014 \\
(-0.57)\end{array}$ & $\begin{array}{l}0.0160^{\mathrm{a}} \\
(6.41)\end{array}$ & $\begin{array}{l}0.0069^{\mathrm{a}} \\
(2.79)\end{array}$ & $\begin{array}{l}0.0072^{\mathrm{a}} \\
(3.05)\end{array}$ & $\begin{array}{l}0.0057^{\mathrm{b}} \\
(2.37)\end{array}$ \\
\hline liquid $_{i t}$ & $\begin{array}{l}0.0010^{\mathrm{d}} \\
(1.46)\end{array}$ & $\begin{array}{l}0.0068^{\mathrm{a}} \\
(7.23)\end{array}$ & $\begin{array}{l}0.0082^{\mathrm{a}} \\
(8.49)\end{array}$ & $\begin{array}{l}0.0082^{\mathrm{a}} \\
(8.40)\end{array}$ & $\begin{array}{l}0.0285^{\mathrm{a}} \\
(30.85)\end{array}$ & $\begin{array}{l}0.0046^{\mathrm{a}} \\
(4.65)\end{array}$ & $\begin{array}{l}0.0098^{\mathrm{a}} \\
(10.67)\end{array}$ & $\begin{array}{l}0.0078^{\mathrm{a}} \\
(8.11)\end{array}$ \\
\hline risk $_{i t}$ & $\begin{array}{l}0.1030^{\mathrm{a}} \\
(7.61)\end{array}$ & $\begin{array}{l}0.1181^{\mathrm{a}} \\
(5.19)\end{array}$ & $\begin{array}{l}0.1096^{\mathrm{a}} \\
(4.85)\end{array}$ & $\begin{array}{l}0.1143^{\mathrm{a}} \\
(4.92)\end{array}$ & $\begin{array}{l}0.1190^{\mathrm{a}} \\
(6.55)\end{array}$ & $\begin{array}{l}0.1257^{\mathrm{a}} \\
(4.88)\end{array}$ & $\begin{array}{l}0.1452^{\mathrm{a}} \\
(7.08)\end{array}$ & $\begin{array}{l}0.1288^{a} \\
(5.33)\end{array}$ \\
\hline$f d_{i t}$ & $\begin{array}{l}-0.0158^{\mathrm{a}} \\
(-3.30)\end{array}$ & $\begin{array}{l}-0.0410^{\mathrm{a}} \\
(-6.21)\end{array}$ & $\begin{array}{l}-0.0427^{\mathrm{a}} \\
(-6.28)\end{array}$ & $\begin{array}{l}-0.0443^{\mathrm{a}} \\
(-6.42)\end{array}$ & $\begin{array}{l}-0.0819^{\mathrm{a}} \\
(12.21)\end{array}$ & $\begin{array}{l}-0.0473^{\mathrm{a}} \\
(-6.79)\end{array}$ & $\begin{array}{l}-0.0517^{\mathrm{a}} \\
(-7.95)\end{array}$ & $\begin{array}{l}-0.0082 \\
(-1.22)\end{array}$ \\
\hline$a g e_{i t}$ & $\begin{array}{l}0.0009^{\mathrm{b}} \\
(2.47)\end{array}$ & $\begin{array}{l}-0.0004 \\
(-0.76)\end{array}$ & $\begin{array}{l}0.0004 \\
(0.73)\end{array}$ & $\begin{array}{l}0.0006 \\
(0.98)\end{array}$ & $\begin{array}{l}0.0018^{\mathrm{a}} \\
(3.64)\end{array}$ & $\begin{array}{l}0.0000 \\
(0.00)\end{array}$ & $\begin{array}{l}0.0008^{\mathrm{c}} \\
(1.66)\end{array}$ & $\begin{array}{l}-0.0003 \\
(-0.52)\end{array}$ \\
\hline$D^{\text {dividend }}$ & $\begin{array}{l}0.0033 \\
(1.07)\end{array}$ & $\begin{array}{l}0.0031 \\
(0.75)\end{array}$ & $\begin{array}{l}-0.0015 \\
(-0.35)\end{array}$ & $\begin{array}{l}-0.0018 \\
(-0.41)\end{array}$ & $\begin{array}{l}0.0034 \\
(0.78)\end{array}$ & $\begin{array}{l}-0.0012 \\
(-0.28)\end{array}$ & $\begin{array}{l}0.0012 \\
(0.28)\end{array}$ & $\begin{array}{l}0.0089^{b} \\
(2.09)\end{array}$ \\
\hline$D^{\text {share }}$ & $\begin{array}{l}-0.0017 \\
(-0.28)\end{array}$ & $\begin{array}{l}-0.0027 \\
(-0.27)\end{array}$ & $\begin{array}{l}-0.0056 \\
(-0.55)\end{array}$ & $\begin{array}{l}-0.0038 \\
(-0.36)\end{array}$ & $\begin{array}{l}-0.0020 \\
(-0.25)\end{array}$ & $\begin{array}{l}0.0068 \\
(0.58)\end{array}$ & $\begin{array}{l}0.0030 \\
(0.32)\end{array}$ & $\begin{array}{l}0.0076 \\
(0.70)\end{array}$ \\
\hline$D^{\text {ownership }}$ & $\begin{array}{l}0.0043 \\
(1.27)\end{array}$ & $\begin{array}{l}0.0044 \\
(0.89)\end{array}$ & $\begin{array}{l}0.0083^{\mathrm{c}} \\
(1.66)\end{array}$ & $\begin{array}{l}0.0087^{\mathrm{c}} \\
(1.69)\end{array}$ & $\begin{array}{l}0.0045 \\
(0.97)\end{array}$ & $\begin{array}{l}0.0073^{\mathrm{d}} \\
(1.37)\end{array}$ & $\begin{array}{l}0.0069^{\mathrm{d}} \\
(1.47)\end{array}$ & $\begin{array}{l}0.0061 \\
(1.20)\end{array}$ \\
\hline$D^{\text {district }}$ & Yes & Yes & Yes & Yes & Yes & Yes & Yes & Yes \\
\hline$D^{\text {dividend }}$ & Yes & Yes & Yes & Yes & Yes & Yes & Yes & Yes \\
\hline Constant & Yes & Yes & Yes & Yes & Yes & Yes & Yes & Yes \\
\hline within & 0.0143 & 0.0139 & 0.0152 & 0.0151 & 0.1654 & 0.0204 & 0.0287 & 0.0167 \\
\hline$R^{2}$ : between & 0.1776 & 0.1509 & 0.1552 & 0.1538 & 0.4666 & 0.1250 & 0.2074 & 0.1716 \\
\hline overall & 0.0828 & 0.0866 & 0.0862 & 0.0861 & 0.3066 & 0.0802 & 0.1181 & 0.1075 \\
\hline Wald chi ${ }^{2}(54)$ & $202.02^{\mathrm{a}}$ & $171.11^{\mathrm{a}}$ & $178.24^{\mathrm{a}}$ & $176.22^{\mathrm{a}}$ & $1302.72^{\mathrm{a}}$ & $177.26^{\mathrm{a}}$ & $284.10^{\mathrm{a}}$ & $206.74^{\mathrm{a}}$ \\
\hline Obs & 4332 & 4332 & 4332 & 4332 & 4332 & 4332 & 4332 & 4332 \\
\hline groups & 742 & 742 & 742 & 742 & 742 & 742 & 742 & 742 \\
\hline pergroup avg & 5.8 & 5.8 & 5.8 & 5.8 & 5.8 & 5.8 & 5.8 & 5.8 \\
\hline
\end{tabular}

Note: 1 . GLS estimation method is adopted in the models.

2. Numbers in parameters are $Z$ values.

3. a, b, c, and d represent significant at the level of $0.01,0.05,0.1$ and 0.2 , respectively.

4. "pergroup avg" refers to the average observation years of each group of sampled firms. Decimal fractions are caused by missing data.

Although the above analysis shows that the eight different capital structure deviations are high correlated to each other. Table 6 shows that product market competition exerts significantly different impact on the degree of 
capital structure deviation when different target capital structures are chosen. However, one thing in common is that there is a negative relationship (significantly negative in most models) between product market competition and capital structure deviation, indicating the more fierce competition in product market, the lower the degree of capital structure deviation. Thus H1 is supported.

5.3 Effects of Changes in Product Market Competition on the Dynamic Adjustment of Capital Structure

Estimated results of the effect of change in product market competition of sampled firms on the range of these firms' capital structure adjustment based on different models are presented in Table 7.

Table 7 Effect of Change in Product Market Competition on the Absolute Degree of Capital Structure Deviation

\begin{tabular}{|c|c|c|c|c|c|c|c|c|}
\hline \multirow{2}{*}{$\begin{array}{c}\text { Independent } \\
\text { variables }\end{array}$} & \multicolumn{8}{|c|}{ Degree of capital structure deviation } \\
\hline & bias $_{i t}^{1}$ & bias $_{i t}^{2}$ & bias $_{i t}^{3}$ & bias $_{i t}^{4}$ & bias $_{i t}^{5}$ & bias $_{i t}^{6}$ & bias $_{i t}^{7}$ & bias $_{i t}^{8}$ \\
\hline$\Delta c c_{i t}$ & $\begin{array}{l}-0.0007 \\
(-0.53)\end{array}$ & $\begin{array}{l}-0.0034^{\mathrm{c}} \\
(-1.90)\end{array}$ & $\begin{array}{l}-0.0029^{d} \\
(-1.57)\end{array}$ & $\begin{array}{l}-0.0031^{\mathrm{c}} \\
(-1.67)\end{array}$ & $\begin{array}{l}-0.0019 \\
(-0.98)\end{array}$ & $\begin{array}{l}-0.0006 \\
(-0.34)\end{array}$ & $\begin{array}{l}-0.0025^{\mathrm{d}} \\
(-1.40)\end{array}$ & $\begin{array}{l}-0.0043^{b} \\
(-2.38)\end{array}$ \\
\hline size $_{i t}$ & $\begin{array}{l}-0.0026^{\mathrm{d}} \\
(-1.35)\end{array}$ & $\begin{array}{l}-0.0045^{\mathrm{d}} \\
(-1.49)\end{array}$ & $\begin{array}{l}-0.0032 \\
(-1.04)\end{array}$ & $\begin{array}{l}-0.0033 \\
(-1.06)\end{array}$ & $\begin{array}{l}0.0048^{\mathrm{c}} \\
(1.76)\end{array}$ & $\begin{array}{l}0.0016 \\
(0.49)\end{array}$ & $\begin{array}{l}0.0003 \\
(0.10)\end{array}$ & $\begin{array}{l}-0.0094^{\mathrm{a}} \\
(-2.99)\end{array}$ \\
\hline mortgage $_{i t}$ & $\begin{array}{l}-0.0037 \\
(-1.20)\end{array}$ & $\begin{array}{l}-0.0091^{\mathrm{b}} \\
(-2.08)\end{array}$ & $\begin{array}{l}-0.0063^{\mathrm{d}} \\
(-1.41)\end{array}$ & $\begin{array}{l}-0.0069^{d} \\
(-1.50)\end{array}$ & $\begin{array}{l}0.0296^{\mathrm{a}} \\
(6.65)\end{array}$ & $\begin{array}{l}-0.0012 \\
(-0.25)\end{array}$ & $\begin{array}{l}-0.0011 \\
(-0.26)\end{array}$ & $\begin{array}{l}-0.0084^{\mathrm{c}} \\
(-1.85)\end{array}$ \\
\hline profit $_{i t}$ & $\begin{array}{l}0.0006^{\mathrm{c}} \\
(1.87)\end{array}$ & $\begin{array}{l}0.0013^{\mathrm{a}} \\
(2.93)\end{array}$ & $\begin{array}{l}0.0009^{\mathrm{b}} \\
(1.96)\end{array}$ & $\begin{array}{l}0.0009^{c} \\
(1.89)\end{array}$ & $\begin{array}{l}0.0010^{c} \\
(1.92)\end{array}$ & $\begin{array}{l}0.0020^{\mathrm{a}} \\
(4.17)\end{array}$ & $\begin{array}{l}0.0020^{\mathrm{a}} \\
(4.35)\end{array}$ & $\begin{array}{l}0.0014^{\mathrm{a}} \\
(3.03)\end{array}$ \\
\hline$n d t s_{i t}$ & $\begin{array}{l}-0.0269^{b} \\
(-2.00)\end{array}$ & $\begin{array}{l}0.0287^{\mathrm{d}} \\
(1.44)\end{array}$ & & $\begin{array}{l}0.0189 \\
(0.91)\end{array}$ & $\begin{array}{l}-0.0493^{\mathrm{a}} \\
(-2.63)\end{array}$ & $\begin{array}{l}0.0126 \\
(0.58)\end{array}$ & $\begin{array}{l}-0.0189 \\
(-0.98)\end{array}$ & $\begin{array}{l}-0.0068 \\
(-0.33)\end{array}$ \\
\hline grow $_{i t}$ & $\begin{array}{l}-0.0006 \\
(-0.51)\end{array}$ & $\begin{array}{l}-0.0016 \\
(-1.00)\end{array}$ & $\begin{array}{l}-0.0034^{b} \\
(-2.00)\end{array}$ & $\begin{array}{l}-0.0027^{\mathrm{d}} \\
(-1.57)\end{array}$ & $\begin{array}{l}0.0217^{\mathrm{a}} \\
(12.03)\end{array}$ & $\begin{array}{l}0.0053^{\mathrm{a}} \\
(3.03)\end{array}$ & $\begin{array}{l}0.0039^{b} \\
(2.35)\end{array}$ & $\begin{array}{l}0.0062^{\mathrm{a}} \\
(3.69)\end{array}$ \\
\hline unique $_{i t}$ & $\begin{array}{l}-0.0018 \\
(-0.94)\end{array}$ & $\begin{array}{l}-0.0014 \\
(-0.56)\end{array}$ & $\begin{array}{l}-0.0049^{c} \\
(-1.88)\end{array}$ & $\begin{array}{l}-0.0049^{\mathrm{c}} \\
(-1.86)\end{array}$ & $\begin{array}{l}0.0186^{\mathrm{a}} \\
(6.73)\end{array}$ & $\begin{array}{l}0.0071^{\mathrm{a}} \\
(2.65)\end{array}$ & $\begin{array}{l}0.0075^{\mathrm{a}} \\
(2.91)\end{array}$ & $\begin{array}{l}0.0058^{b} \\
(2.24)\end{array}$ \\
\hline liquid $_{i t}$ & $\begin{array}{l}0.0007 \\
(0.93)\end{array}$ & $\begin{array}{l}0.0068^{\mathrm{a}} \\
(6.88)\end{array}$ & $\begin{array}{l}0.0075^{\mathrm{a}} \\
(7.35)\end{array}$ & $\begin{array}{l}0.0075^{\mathrm{a}} \\
(7.26)\end{array}$ & $\begin{array}{l}0.0294^{\mathrm{a}} \\
(29.49)\end{array}$ & $\begin{array}{l}0.0045^{\mathrm{a}} \\
(4.16)\end{array}$ & $\begin{array}{l}0.0096^{\mathrm{a}} \\
(9.84)\end{array}$ & $\begin{array}{l}0.0072^{\mathrm{a}} \\
(7.03)\end{array}$ \\
\hline risk $_{i t}$ & $\begin{array}{l}0.0980^{\mathrm{a}} \\
(6.88)\end{array}$ & $\begin{array}{l}0.0912^{\mathrm{a}} \\
(3.86)\end{array}$ & $\begin{array}{l}0.0886^{\mathrm{a}} \\
(3.75)\end{array}$ & $\begin{array}{l}0.0922^{\mathrm{a}} \\
(3.81)\end{array}$ & $\begin{array}{l}0.1101^{\mathrm{a}} \\
(5.68)\end{array}$ & $\begin{array}{l}0.1041^{\mathrm{a}} \\
(3.85)\end{array}$ & $\begin{array}{l}0.1406^{\mathrm{a}} \\
(6.51)\end{array}$ & $\begin{array}{l}0.1283^{\mathrm{a}} \\
(5.09)\end{array}$ \\
\hline$f d_{i t}$ & $\begin{array}{l}-0.0160^{\mathrm{a}} \\
(-3.08)\end{array}$ & $\begin{array}{l}-0.0346^{\mathrm{a}} \\
(-4.84)\end{array}$ & $\begin{array}{l}-0.0389^{\mathrm{a}} \\
(-5.29)\end{array}$ & $\begin{array}{l}-0.0406^{\mathrm{a}} \\
(-5.45)\end{array}$ & $\begin{array}{l}-0.0759^{a} \\
(-10.23)\end{array}$ & $\begin{array}{l}-0.0365^{a} \\
(-4.77)\end{array}$ & $\begin{array}{l}-0.0457^{\mathrm{a}} \\
(-6.40)\end{array}$ & $\begin{array}{l}-0.0025 \\
(-0.34)\end{array}$ \\
\hline age $_{i t}$ & $\begin{array}{l}0.0017^{\mathrm{a}} \\
(4.44)\end{array}$ & $\begin{array}{l}0.0002 \\
(0.28)\end{array}$ & $\begin{array}{l}0.0005 \\
(0.87)\end{array}$ & $\begin{array}{l}0.0007^{\mathrm{d}} \\
(1.09)\end{array}$ & $\begin{array}{l}0.0018^{\mathrm{a}} \\
(3.29)\end{array}$ & $\begin{array}{l}-0.0004 \\
(-0.66)\end{array}$ & $\begin{array}{l}0.0006 \\
(1.01)\end{array}$ & $\begin{array}{l}-0.0006^{\mathrm{c}} \\
(-0.94)\end{array}$ \\
\hline$D^{\text {dividend }}$ & $\begin{array}{l}0.0019 \\
(0.63)\end{array}$ & $\begin{array}{l}0.0030 \\
(0.72)\end{array}$ & $\begin{array}{l}-0.0040 \\
(-0.35)\end{array}$ & $\begin{array}{l}-0.0021 \\
(-0.50)\end{array}$ & $\begin{array}{l}0.0013 \\
(0.30)\end{array}$ & $\begin{array}{l}-0.0035 \\
(-0.80)\end{array}$ & $\begin{array}{l}0.0002 \\
(0.06)\end{array}$ & $\begin{array}{l}0.0074^{c} \\
(1.73)\end{array}$ \\
\hline$D^{\text {share }}$ & $\begin{array}{l}-0.0025 \\
(-0.39)\end{array}$ & $\begin{array}{l}-0.0013 \\
(-0.12)\end{array}$ & $\begin{array}{l}-0.0063 \\
(-0.58)\end{array}$ & $\begin{array}{l}-0.0048 \\
(-0.43)\end{array}$ & $\begin{array}{l}-0.0030 \\
(-0.34)\end{array}$ & $\begin{array}{l}-0.0073 \\
(-0.59)\end{array}$ & $\begin{array}{l}0.0037 \\
(0.38)\end{array}$ & $\begin{array}{l}0.0064 \\
(0.55)\end{array}$ \\
\hline
\end{tabular}


(Continued)

\begin{tabular}{|c|c|c|c|c|c|c|c|c|}
\hline \multirow{2}{*}{$\begin{array}{c}\text { Independent } \\
\text { variables }\end{array}$} & \multicolumn{8}{|c|}{ Degree of capital structure deviation } \\
\hline & bias $_{i t}^{1}$ & bias $_{i t}^{2}$ & bias $_{i t}^{3}$ & bias $_{i t}^{4}$ & bias $_{i t}^{5}$ & bias $_{i t}^{6}$ & bias $_{i t}^{7}$ & bias $_{i t}^{8}$ \\
\hline$D^{\text {ownership }}$ & $\begin{array}{l}0.0037 \\
(1.03)\end{array}$ & $\begin{array}{l}0.0058 \\
(1.11)\end{array}$ & $\begin{array}{l}0.0086^{\mathrm{d}} \\
(1.62)\end{array}$ & $\begin{array}{l}0.0091^{\mathrm{d}} \\
(1.69)\end{array}$ & $\begin{array}{l}0.0062 \\
(1.23)\end{array}$ & $\begin{array}{l}0.0063 \\
(1.10)\end{array}$ & $\begin{array}{l}0.0071^{\mathrm{d}} \\
(1.41)\end{array}$ & $\begin{array}{l}0.0057 \\
(1.05)\end{array}$ \\
\hline$D^{\text {district }}$ & Yes & Yes & Yes & Yes & Yes & Yes & Yes & Yes \\
\hline$D^{\text {dividend }}$ & Yes & Yes & Yes & Yes & Yes & Yes & Yes & Yes \\
\hline Constant & Yes & Yes & Yes & Yes & Yes & Yes & Yes & Yes \\
\hline within & 0.0067 & 0.0126 & 0.0135 & 0.0132 & 0.1678 & 0.0154 & 0.0230 & 0.0136 \\
\hline$R^{2}:$ between & 0.1767 & 0.1416 & 0.1416 & 0.1416 & 0.4751 & 0.1159 & 0.2096 & 0.1751 \\
\hline overall & 0.0847 & 0.0873 & 0.0856 & 0.0861 & 0.3283 & 0.0786 & 0.1249 & 0.1124 \\
\hline Wald $\operatorname{chi}^{2}(54)$ & $167.73^{\mathrm{a}}$ & $146.54^{\mathrm{a}}$ & $148.55^{\mathrm{a}}$ & $147.51^{\mathrm{a}}$ & $1201.98^{\mathrm{a}}$ & $137.74^{\mathrm{a}}$ & $243.72^{\mathrm{a}}$ & $181.37^{\mathrm{a}}$ \\
\hline Obs & 3661 & 3661 & 3661 & 3661 & 3661 & 3661 & 3661 & 3661 \\
\hline groups & 741 & 741 & 741 & 741 & 741 & 741 & 741 & 741 \\
\hline pergroup avg & 4.9 & 4.9 & 4.9 & 4.9 & 4.9 & 4.9 & 4.9 & 4.9 \\
\hline
\end{tabular}

Note: 1 . GLS estimation method is adopted in the models.

2. Numbers in parameters are $Z$ values.

3. a, b, c, and d represent significant at the level of $0.01,0.05,0.1$ and 0.2 , respectively.

4. "pergroup avg" refers to the average observation years of each group of sampled firms. Decimal fractions are caused by missing data.

As shown in Table 7, results of chi-square test show that all eight models are statistically significant. Among them, the range of capital structure adjustment is negatively related to intensification of product market competition and such a negative relationship is significant in most of the models. Thus $\mathrm{H} 2$ is supported.

Table 6 and 7 shows that all control variables such as profitability, asset liquidity, business risks have significantly positive and robust impact on the capital structure deviation. Cash requirement is significantly and negatively related to capital structure deviation. Such a relationship also demonstrates robustness to a certain degree. We also find that, compared with state-owned listed companies, non-state-owned listed companies have greater capital structure deviation. However, such a finding is not significant in some models. Other control variables only have statistically insignificant impact on capital structure deviation.

5.4 Impact of Product Market Competition on the Speed of Capital Structure Adjustment

Table 8 depicts the regression results of the relationship between product market competition and the speed of capital structure adjustment by adopting eight different calculation approaches. 
Table 8 Impact of Product Market Competition on the Speed of Capital Structure Adjustment

\begin{tabular}{|c|c|c|c|c|c|c|c|c|}
\hline \multirow{3}{*}{$\begin{array}{c}\text { Independent } \\
\text { variables }\end{array}$} & \multicolumn{8}{|c|}{ Speed of capital structure adjustment } \\
\hline & $\delta_{i t}^{1}$ & $\delta_{i t}^{2}$ & $\delta_{i t}^{3}$ & $\delta_{i t}^{4}$ & $\delta_{i t}^{5}$ & $\delta_{i t}^{6}$ & $\delta_{i t}^{7}$ & $\delta_{i t}^{8}$ \\
\hline & (1) & (2) & (3) & (4) & (5) & (6) & $(7)$ & (8) \\
\hline$c c_{i t}$ & $\begin{array}{l}0.6068 \\
(0.32)\end{array}$ & $\begin{array}{l}-1.3721 \\
(-0.31)\end{array}$ & $\begin{array}{l}-0.8006^{\mathrm{d}} \\
(-1.34)\end{array}$ & $\begin{array}{l}-0.3087 \\
(-0.64)\end{array}$ & $\begin{array}{l}0.0352 \\
(0.05)\end{array}$ & $\begin{array}{l}0.2659 \\
(0.32)\end{array}$ & $\begin{array}{l}0.6174^{\mathrm{d}} \\
(1.29)\end{array}$ & $\begin{array}{l}-0.0850 \\
(-0.30)\end{array}$ \\
\hline size $_{i t}$ & $\begin{array}{l}-1.2988 \\
(-0.74)\end{array}$ & $\begin{array}{l}4.2114 \\
(0.93)\end{array}$ & $\begin{array}{l}0.0066 \\
(0.01)\end{array}$ & $\begin{array}{l}-0.0744 \\
(-0.16)\end{array}$ & $\begin{array}{l}0.0878 \\
(0.13)\end{array}$ & $\begin{array}{l}-0.9814 \\
(-1.26)\end{array}$ & $\begin{array}{l}-0.3901 \\
(-0.88)\end{array}$ & $\begin{array}{l}-0.1278 \\
(-0.49)\end{array}$ \\
\hline mortgage $_{i t}$ & $\begin{array}{l}-0.0780 \\
(-0.02)\end{array}$ & $\begin{array}{l}-2.0175 \\
(-0.21)\end{array}$ & $\begin{array}{l}-0.5686 \\
(-0.45)\end{array}$ & $\begin{array}{l}-0.1914 \\
(-0.19)\end{array}$ & $\begin{array}{l}-0.1443 \\
(-0.09)\end{array}$ & $\begin{array}{l}-0.5558 \\
(-0.31)\end{array}$ & $\begin{array}{l}-0.6300 \\
(-0.62)\end{array}$ & $\begin{array}{l}-0.3121 \\
(-0.53)\end{array}$ \\
\hline profit $_{i t}$ & $\begin{array}{l}-0.0214 \\
(-0.04)\end{array}$ & $\begin{array}{l}0.0106 \\
(0.01)\end{array}$ & $\begin{array}{l}-0.0227 \\
(-0.14)\end{array}$ & $\begin{array}{l}0.0139 \\
(0.11)\end{array}$ & $\begin{array}{l}0.0984 \\
(0.49)\end{array}$ & $\begin{array}{l}0.0324 \\
(0.14)\end{array}$ & $\begin{array}{l}-0.0239 \\
(-0.18)\end{array}$ & $\begin{array}{l}0.0166 \\
(0.22)\end{array}$ \\
\hline$n d t s_{i t}$ & $\begin{array}{l}-7.9019 \\
(-0.61)\end{array}$ & $\begin{array}{l}12.7232 \\
(0.38)\end{array}$ & $\begin{array}{l}1.0900 \\
(0.27)\end{array}$ & $\begin{array}{l}-2.1907 \\
(-0.65)\end{array}$ & $\begin{array}{c}0.7314 \\
(-0.01)\end{array}$ & $\begin{array}{l}7.7377^{\mathrm{d}} \\
(1.34)\end{array}$ & $\begin{array}{l}-0.6184 \\
(-0.19)\end{array}$ & $\begin{array}{l}1.1031 \\
(0.57)\end{array}$ \\
\hline grow $_{i t}$ & $\begin{array}{l}0.2765 \\
(0.15)\end{array}$ & $\begin{array}{l}1.6940 \\
(0.40)\end{array}$ & $\begin{array}{l}1.0327^{\mathrm{c}} \\
(1.79)\end{array}$ & $\begin{array}{l}0.4292 \\
(0.92)\end{array}$ & $\begin{array}{l}0.1433 \\
(0.20)\end{array}$ & $\begin{array}{l}0.5453 \\
(0.68)\end{array}$ & $\begin{array}{l}0.0236 \\
(0.05)\end{array}$ & $\begin{array}{l}0.2715 \\
(1.01)\end{array}$ \\
\hline unique $_{i t}$ & $\begin{array}{l}1.7764 \\
(0.70)\end{array}$ & $\begin{array}{l}0.7427 \\
(0.12)\end{array}$ & $\begin{array}{l}-1.2374^{\mathrm{d}} \\
(-1.53)\end{array}$ & $\begin{array}{l}-0.2846 \\
(-0.43)\end{array}$ & $\begin{array}{l}-0.0335 \\
(-0.03)\end{array}$ & $\begin{array}{l}-0.2048 \\
(-0.18)\end{array}$ & $\begin{array}{l}0.0757 \\
(0.12)\end{array}$ & $\begin{array}{l}-0.1465 \\
(-0.39)\end{array}$ \\
\hline liquid $_{i t}$ & $\begin{array}{l}-0.5212 \\
(-0.68)\end{array}$ & $\begin{array}{l}1.1396 \\
(0.59)\end{array}$ & $\begin{array}{l}-0.1795 \\
(-0.74)\end{array}$ & $\begin{array}{l}-0.0318 \\
(-0.16)\end{array}$ & $\begin{array}{l}-0.1355 \\
(-0.44)\end{array}$ & $\begin{array}{l}0.0676 \\
(-0.20)\end{array}$ & $\begin{array}{l}0.0032 \\
(0.02)\end{array}$ & $\begin{array}{l}-0.0003 \\
(-0.00)\end{array}$ \\
\hline risk $_{i t}$ & $\begin{array}{l}4.0355 \\
(0.35)\end{array}$ & $\begin{array}{l}20.5058 \\
(0.68)\end{array}$ & $\begin{array}{l}-3.8759 \\
(-1.06)\end{array}$ & $\begin{array}{l}4.9879^{\mathrm{c}} \\
(1.66)\end{array}$ & $\begin{array}{l}-1.0284 \\
(-0.23)\end{array}$ & $\begin{array}{l}-6.4375^{\mathrm{d}} \\
(1.26)\end{array}$ & $\begin{array}{l}-2.4164 \\
(-0.83)\end{array}$ & $\begin{array}{l}1.1846 \\
(0.70)\end{array}$ \\
\hline$f d_{i t}$ & $\begin{array}{l}0.3173 \\
(0.05)\end{array}$ & $\begin{array}{l}8.2282 \\
(0.56)\end{array}$ & $\begin{array}{l}0.0014 \\
(0.00)\end{array}$ & $\begin{array}{l}-0.1771 \\
(-0.11)\end{array}$ & $\begin{array}{l}1.9767 \\
(0.83)\end{array}$ & $\begin{array}{l}1.3988 \\
(0.52)\end{array}$ & $\begin{array}{l}1.6815 \\
(1.10)\end{array}$ & $\begin{array}{l}-1.2365^{\mathrm{d}} \\
(-1.39)\end{array}$ \\
\hline age $_{i t}$ & $\begin{array}{l}-0.4094 \\
(-1.21)\end{array}$ & $\begin{array}{l}0.4138 \\
(0.47)\end{array}$ & $\begin{array}{l}-0.0405 \\
(-0.38)\end{array}$ & $\begin{array}{c}0.0609 \\
(0.69)\end{array}$ & $\begin{array}{l}0.0068 \\
(0.05)\end{array}$ & $\begin{array}{l}0.9704^{\mathrm{a}} \\
(6.42)\end{array}$ & $\begin{array}{l}-0.0233 \\
(-0.27)\end{array}$ & $\begin{array}{l}-0.0126 \\
(-0.25)\end{array}$ \\
\hline$D^{\text {dividend }}$ & $\begin{array}{l}0.1349 \\
(0.03)\end{array}$ & $\begin{array}{l}3.7595 \\
(0.37)\end{array}$ & $\begin{array}{l}-0.9079 \\
(-0.66)\end{array}$ & $\begin{array}{l}-1.7407^{\mathrm{d}} \\
(-1.56)\end{array}$ & $\begin{array}{l}2.8426^{\mathrm{c}} \\
(1.65)\end{array}$ & $\begin{array}{l}-1.8049 \\
(-0.94)\end{array}$ & $\begin{array}{l}2.1436^{\mathrm{c}} \\
(1.95)\end{array}$ & $\begin{array}{l}0.5590 \\
(0.87)\end{array}$ \\
\hline$D^{\text {share }}$ & $\begin{array}{l}-3.8353 \\
(-0.74)\end{array}$ & $\begin{array}{l}-3.0035 \\
(-0.22)\end{array}$ & $\begin{array}{l}-0.2084 \\
(-0.11)\end{array}$ & $\begin{array}{l}0.6790 \\
(0.50)\end{array}$ & $\begin{array}{l}-0.0776 \\
(-0.04)\end{array}$ & $\begin{array}{l}-1.3564 \\
(-0.59)\end{array}$ & $\begin{array}{l}0.4976 \\
(0.38)\end{array}$ & $\begin{array}{l}0.4711 \\
(0.62)\end{array}$ \\
\hline$D^{\text {ownership }}$ & $\begin{array}{l}-1.1890 \\
(-0.33)\end{array}$ & $\begin{array}{c}0.6580 \\
(-0.07)\end{array}$ & $\begin{array}{c}0.3531 \\
(-0.31)\end{array}$ & $\begin{array}{l}-0.4044 \\
(-0.43)\end{array}$ & $\begin{array}{l}2.9540^{\mathrm{b}} \\
(2.08)\end{array}$ & $\begin{array}{l}-0.4001 \\
(-0.25)\end{array}$ & $\begin{array}{l}0.2751 \\
(0.30)\end{array}$ & $\begin{array}{l}-0.0401 \\
(-0.08)\end{array}$ \\
\hline$D^{\text {district }}$ & Yes & Yes & Yes & Yes & Yes & Yes & Yes & Yes \\
\hline$D^{\text {dividend }}$ & Yes & Yes & Yes & Yes & Yes & Yes & Yes & Yes \\
\hline Cons tan $t$ & Yes & Yes & Yes & Yes & Yes & Yes & Yes & Yes \\
\hline within & 0.0004 & 0.0002 & 0.0023 & 0.0010 & 0.0016 & 0.0001 & 0.0023 & 0.0006 \\
\hline$R^{2}$ : between & 0.1113 & 0.1217 & 0.0348 & 0.0577 & 0.0588 & 0.1214 & 0.0624 & 0.0535 \\
\hline overall & 0.0189 & 0.0216 & 0.0078 & 0.0109 & 0.0113 & 0.0184 & 0.0125 & 0.0095 \\
\hline Wald $\operatorname{chi}^{2}(54)$ & $82.18^{\mathrm{a}}$ & $79.46^{\mathrm{d}}$ & 33.44 & 45.83 & 48.77 & $80.35^{\mathrm{d}}$ & 53.94 & 41.15 \\
\hline Obs & 4332 & 4332 & 4332 & 4332 & 4332 & 4332 & 4332 & 4332 \\
\hline groups & 742 & 742 & 742 & 742 & 742 & 742 & 742 & 742 \\
\hline pergroup avg & 5.8 & 5.8 & 5.8 & 5.8 & 5.8 & 5.8 & 5.8 & 5.8 \\
\hline
\end{tabular}

Note: 1. GLS estimation method is adopted in the models.

2. Numbers in parameters are $Z$ values.

3. a, b, c, and d represent significant at the level of $0.01,0.05,0.1$ and 0.2 , respectively. 4. "pergroup avg" refers to the average observation years of each group of sampled firms. Decimal fractions are caused by missing data. 
As depicted in Table 8, chi-square test (i.e., Wald $\left.\operatorname{chi}^{2}(54)\right)$ results show that only Model (1), (2) and (6) are significant out of the eight models. Out of the insignificant models, only Model (3) and (7) demonstrate a positive relationship between product market competition and speed of capital structure adjustment. All these show that the impact of product market competition on the speed of capital structure adjustment is neither significant nor robust. Likewise, most of the other control variables are insignificantly related to the speed of capital structure adjustment.

We also test the relationship between changes in product market competition and the speed of capital structure adjustment from the dynamic perspective. Results show that the relationship between the two is not statistically significant. Below, to better demonstrate the relationship between relationship between changes in product market competition and the speed of capital structure adjustment, we conduct a contingency table analysis on the relationship.

Table 9 Relationship Between Dynamic Changes in Product Market Competition and the Speed of Capital Structure Adjustment

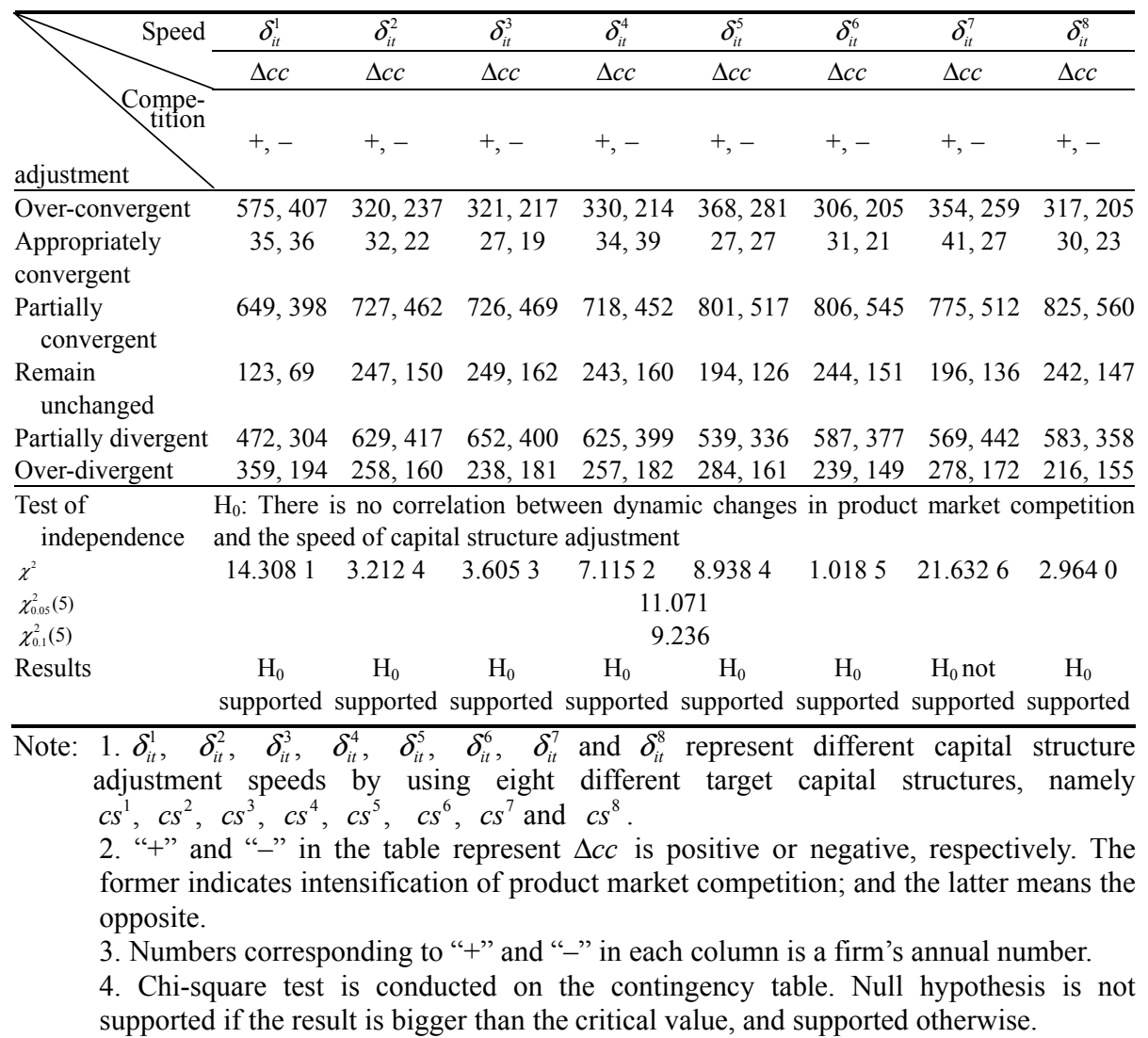


As shown in Table 9, we use annual industrial mean, mixed industrial mean, industrial median, regression estimate of panel data, regression estimate of the fixed effect of panel data, and estimate of Tobin regression as target value respectively and conduct independence test on the relationship between dynamic changes of product market competition and adjustment of $\delta_{i t}^{2}, \delta_{i t}^{3}, \delta_{i t}^{4}, \delta_{i t}^{5}, \delta_{i t}^{6}$ and $\delta_{i t}^{8}$. The results show that there is no significant relationship between dynamic changes of product market competition and capital structure adjustment. However, a complete opposite conclusion is obtained ( $\delta_{i t}^{1}$ and $\delta_{i t}^{7}$ ) when the mean of time series data of capital structure and the estimated value of GLS regression of the random effects of panel data are used as target value. Which of the two conclusions is correct? Further regression test on $\delta_{i t}^{1}$ and $\delta_{i t}^{7}$ finds that both conclusions are insignificantly negative. Thus, we conclude that dynamic changes in product market competition and the speed change of capital structure adjustment is independent of each other. Considering there is no significant correlation among all the eight speeds, the above conclusion is robust.

Therefore, $\mathrm{H} 3$ is not supported. The reason behind this might be that there is small degree of capital structure deviation among China's listed companies. Therefore, the speed of capital structure adjustment might not exert significant impact on firm security. Meanwhile, as some researchers (Banerjee, Heshmati and Wihlborg, 2000; Tong, 2004) have already proved the existence of capital structure adjustment, the above conclusion might also have something to do with the high adjustment cost of Chinese listed companies caused by undeveloped financial institutes and capital markets.

\section{Conclusion}

A firm's decision on capital structure is closely related to its product market competition. Product market competition not only influences a firm's static choice of capital structure, but also its dynamic adjustment of capital structure. By using parallel panel data in 1999-2004, we explored the relationship between product market competition and dynamic adjustment of capital structure from both static and dynamic perspectives. Our results show that, statically and dynamically, product market competition significantly influences a firm's capital structure deviation. Specifically, the fiercer the product market competition, the smaller the degree of capital structure deviation. However, we find no evidence showing there is any significant correlation between dynamic changes in product market competition and speed of capital structure adjustment. Possible explanations might include small degree of capital structure deviation among China's listed companies, little impact of capital structure adjustment on firm 
safety, and high capital structure adjustment cost, etc.

The contributions of this article are as follows: first, we further extend study in the field of financial strategy. Since Brand and Lewis' pioneer study in the field, most of the followed study was conducted from the perspective of static perspective. Extant literature has paid little attention to the impact of product market competition on the dynamic adjustment of capital structure or impact of change in product market competition on the dynamic adjustment of capital structure. To fill in this gap, this article explores the impact of product market competition on the dynamic adjustment of capital structure from both static and dynamic perspectives; secondly, since Jalivand and Harris' pioneer study on the dynamic adjustment of capital structure, few researchers have studied the issue from a cross-discipline perspective. Based on the industrial organization theory, this paper studies the impact of product market competition on the deviation degree of present capital structure from target one and the speed of capital structure adjustment. By doing so, we introduce into extant literature the new variable of dynamic adjustment of capital structure, thus further expand the present study on the relationship between product market competition and its changes and the speed of capital structure adjustment.

This study has important practical implications: when making decisions on capital structure, a firm needs to take into consideration the degree of competition of its product market. The more fierce the degree of competition in its product market, the more the firm should reduce its capital structure deviation, so as to ensure its finance robustness, prevent its rivals' strategic behaviors, and avoid falling into financial difficulties. In addition, this study helps us to gain a better understanding of the decision-making process of capital structure.

One of the important limitations of this article lies in that we find ourselves unable to find a better proxy variable to replace product market competition to conduct robustness test due to several important reasons such as difficulty in defining explicitly a firm's product market, the complexity of product market competition index itself, and difficulty in obtaining sampled firms' sales revenue data. Therefore, the reliability of this article's conclusions might be influenced to a certain degree. Future study needs to spend more effort on preferring the indicator(s) of product market competition to make it better reflect reality and reach more reliable and robust conclusions.

Acknowledgements This work is supported by the Scientific Research Foundation of Renmin University of China (No. 07XNA005), the National Natural Science Foundation of China (No. 70532002 and No. 70473094), and the project of Key Research Institute of Humanitites and Social Sciences in Universities (No. 05JJD630029). Special thanks go to the two anonymous reviewers for their valuable suggestions. 


\section{References}

Antoniou A, Guney Y, Paudyal K (2002). Determinants of corporate capital structure: Evidence from European countries. Working paper, University of Durham

Banerjee H, Heshmati A, Wihlborg C (2000). The dynamics of capital structure. Stockolm School of Economics, Working paper series in Economics and Finance, No.333

Bolton P, Scharfstein D (1990). A Theory of predation based on agency problems in financial contracting. American Economic Review, 80: 93-106

Booth L, Aivazian V, Kunt A D, Maksimovic V (2001). Capital structure in developing countries. Journal of Finance, 56(1): 87-130

Brander J, Lewis T (1986). Oligopoly and financial structure: The limited liability effect. American Economic Review, 76: 956-970

Brander J, Lewis T (1988). Bankruptcy costs and the theory of oligopoly. Canadian Journal of Economics, 21: 221-243

Byoun S (2008). How and when do firms adjust their capital structures toward targets? Journal of Finance, 63: 3069-3096

D'Mello R, Farhat J (2002). A comparative analysis of proxies for target capital structure. Working Paper

De Jong A, Nguyen T T, Mathijs M A (2007). Strategic debt: Evidence from bertrand and cournot competition. SSRN Working paper

Dittmar A, Thakor A (2007). Why do firms issue equity? Journal of Finance, 62: 1-54

Evgeny L (2002). Capital structure and interaction among firms in output markets: Theory and evidence. Research paper, 29th annual meeting of European Finance Association, Berlin, Aug, 2002

Fischer E O, Heinkel R, Zechner J (1989). Dynamic capital structure choice: Theory and tests. Journal of Finance, 46(1): 297-355

Flannery M, Rangan K P (2006). Partial adjustment toward target capital structures. Journal of Financial Economics, 79(3): 469-506

Graham J R, Harvey C R (2001). The theory and practice of corporate finance: Evidence from the field. Journal of Financial Economics, 60: 187-243

Gujarati D N (2000). 计量经济学 (Econometrics). Third Edition. Trans.: 林少宫 (Lin Shaogong). 北京: 中国人民大学出版社, 594

Heshmati A (2002). The dynamics of capital structure: Evidence from Swedish micro and small firms. Research in Banking and Finance, 2: 199-241

Jalivand A, Harris R (1984). Corporate behavior in adjustment to capital structure and dividend targets: An econometric study. Journal of Finance, 39(1): 127-145

Kraus A, Litzenberger R (1973). A state-performance model of optimal financial leverage. Journal of Finance, 28: 911-922

Levy A, Hennssy C (2007). Why dose capital structure choice vary with macroeconomic conditions? Journal Monetary Economics, 54: 1545-1564

Liu L X (2005). Do firms have target leverage ratios? Evidence from historical market-to-book vand past returns. SSRN Working paper

Lööf H (2004). Dynamic optimal capital structure and technical change. Structural Change and Economic Dynamics, 15: 449-468

Modigliani F, Miller M (1958). The cost of capital, corporation finance and the theory of investment. American Economics Review, 48: 261-297

Nickell S (1996). Competition and corporate performance. Journal of Political Economy, 104: 
724-746

Rajan R G, Zingales L (1995). What do we know about capital structure: Some evidence from international data. Journal of Finance, 5(12): 1203-1235

Rajbhandary A (1997). Capital structure of firms in developing countries: Results for India. Unpublished Manuscript

Schnitzer M, Wambach A (1998). Inside versus outside financing and product market competition. Discussion Paper of the Munich Economics Department, No. 25-98

Scott J H (1976). A theory of optimal capital structure. Bell Journal of Economics, 7: 33-54

Sheridan T, Sergey T (2007). A dynamic model of optimal capital structure. Review of Finance, (11)3: 401-451

Shinichi N, Naohiko B (2004). Dynamic capital structure of Japanese firms: How far has the deduction of excess leverage progressed in Japan? Bank of Japan Working Paper Series

Showalter D (1995). Oligopoly and financial structure: Comment. American Economic Review, (85)3: 647-653

Telser L (1966). Cutthroat competition and the long purse. Journal of Law and Economics, 9: $259-277$

Tirole J (2007). 公司金融理论 (The Theory of Corporate Finance). Trans.: 王永钦等 (Wang Yongqin et al.). 北京: 中国人民大学出版社

Tucker J and Evarist S (2007). Long and short run capital structure dynamics in the UK: An industry level study. SSRN Working paper

Wanzenried G (2000). Capital structure decision and output market competition under demand uncertainty. http: //www-vwi.unibe.ch/theory/ papers/wanzenried

姜付秀, 刘志彪, 陆正飞 (Jiang Fuxiu, Liu Zhibiao, Lu Zhengfei) (2006). 多元化经营、企业价值 与受益波动研究 (Diversification, firm's value and earnings fluctuation: An empirical research based on Chinese listed firms). 财经问题研究, (11): 27-35

连玉君 (Lian Yujun) (2005). 中国上市公司资本结构动态调整机制研究 (The dynamic adjustment of firms' capital structure in China). Working Paper, 经济发展论坛

刘志彪, 姜付秀, 卢二坡 (Liu Zhibiao, Jiang Fuxiu, Lu erpo) (2003). 资本结构与产品市场竞争 (Capital structure and product market competition). 经济研究, (7): 60-67

陆正飞, 高强 (Lu Zhengfei, Gao Qiang) (2003). 中国上市公司融资行为研究——基于问卷调查 的分析 (Study on financing behavior of listed companies in China-Analyses based on a questionnaire). 会计研究, (10): 16-25

屈耀辉 (Qü Yaohui) (2006) 中国上市公司资本结构的调整速度以及影响因素 (Adjustment speed and its determinants of capital structure of Chinese listed companies: An empirical analysis from unbalanced panel data). 会计研究, (6): 56-63

童勇 (Tong Yong) (2004). 资本结构的动态调整和影响因素 (Dynamic adjustment of capital structure and the determinants). 财经研究, (10): 96-104

王皓, 赵俊 (Wang Hao, Zhao Jun) (2004). 资本结构动态调整模型 (Study on the model of dynamic adjustment of capital structure). 经济科学, (3): 54-62

肖作平 (Xiao Zuoping) (2004). 资本结构影响因素和双向效应动态模型 (Determinants of capital structure and a two-way effects dynamic model). 会计研究, (2): 36-41

赵蒲, 孙爱英 (Zhao Pu, Sun Aiying) (2004). 财务保守行为: 基于中国上市公司的实证研究 (Financial conservatism: An empirical study on China's listed firms). 管理世界, (11): 109-119

朱武祥, 陈寒梅, 吴迅 (Zhu Wuxiang, Chen Hanmei, Wu Xun) (2002). 产品市场竞争与财务保 守行为——燕京啤酒为例的分析 (Product market competition and financial conservatism: A case study of Yanjing Beer). 经济研究, (8): 28-37 